\section{Shannon Mattern}

Dept. of Media Studies and Film The New School

2 West 13th Street, 12th Floor

New York, NY 10011 USA matterns@newschool.edu

Keywords: Louis Kahn, acoustics, libraries, design analysis, meaning, symbolism, geometry

\section{Research}

\section{Geometries of Reading, Light of Learning: Louis I. Kahn's Library at Phillips Exeter}

Abstract. In Louis I. Kahn's library at Phillips Exeter Academy geometries of architecture and media function as parallel rhetorical systems, sometimes complementing, sometimes contradicting one another. This present paper examines how the geometric forms of the library shape patrons' relationships to media in the collection, and how Kahn's elementary geometries have accommodated new media characterized by non-geometric, non-linear forms.

\title{
Introduction
}

Sarah Williams Goldhagen describes Louis I. Kahn's library at Phillips Exeter Academy as a "great brick packing crate of a building that is dominated inside by geometries of circles inscribed in squares; natural light pours in around an improbably heavy X-shaped cross high above" [2001: 1]. Kahn himself uses a different geometrical language to describe his design:

I made the outer depth of the building like a brick doughnut.... I made the inner depth of the building like a concrete doughnut, where the books are stored away from the light. The central area is a result of these two contiguous doughnuts; it's just the entrance where books are visible all around you through the big circular openings. So you feel the building has the invitation of books [quoted in Architectural Forum 1972: 77].

Designed from the outside in, as a box within a box, the library's outermost volume features rows of private reading carrels along its exterior walls, while the intermediate ring houses the book stacks, and the ceremonial hall in the center offers a place to meet and be inspired by views of the library's collection.

In the nearly forty years since Kahn's library began welcoming students at this exclusive prep school in southern New Hampshire, countless critics and historians have addressed the functionality and symbolism of the library's exterior and interior geometries, how that geometry filters light and directs the flow of visitors; and how Kahn's design manifests his interpretation of the essential Form of the library-asinstitution. In that same period, and for decades prior, some of those same critics and historians have searched for material evidence, throughout Kahn's entire oeuvre, of his "knowledge of architectural history, transformed by his fascination with geometry, and placed at the service of his ideas about the nature" of human institutions [Wickersham 1989: 140]. Using several of Kahn's buildings as examples, Robert McCarter, author of one of the many monographs on the architect, explains how Kahn made "the archaic... architectural through engaging the most fundamental of geometries and eternal ordering principles" [2005: 446]. William Jordy [1974], Hisao Koyama [1983], Vincent Scully [1989], Jay Wickersham [1989], Peter Kohane [1990], and McCarter [2005] have all examined the influence of Kahn's Beaux Arts training and his complex relation to Modernism and the International Style on his practice, and the impress of particular 
historical precedents - the medieval monastic library, the monastery cloister of Bramante's S. Maria della Pace, the Renaissance palazzo, Étienne Louis Boullée's drawing of a "Library Hall," Frank Lloyd Wright's Unity Temple - on Exeter, in particular. At Exeter, Vincent Scully argues, Kahn found "a diagrammatic realization of the Neoplatonic order indestructible within the ruin" [2003: 317]. "Kahn sought to reduce the [library] to the simplest possible statement of pure geometric shapes," Jay Wickersham writes, "a sphere within the cube of the central hall, within the larger cube of the building's exterior mass” [1989: 148-149].

Yet Goldhagen, in Louis Kahn's Situated Modernisms, strives to dispel the myth that Kahn was a "conservative mystical thinker who sought to discover or create geometric archetypes of universal significance" - that Kahn, a "latter-day neo-Platonist, ... believed it was the architect's job to 'discover' ideal forms and then re-embody these archetypes in a new architectural language” [2001: 2]. She argues that

Kahn himself encouraged this vision of his agenda, particularly toward the end of his life when, under the influence of spiritually minded architects, mostly from the Indian subcontinent, he retroactively described his architectural agenda in the obfuscatory and transcendentalizing terms for which he is well known [Goldhagen 2001: 2].

Much ink has already been spilt in this debate, and it is not my intention to resolve it here. The focus on biographical histories of Kahn's design and this auteur-ish approach to design analysis, I think, steal attention from the social and experiential aspects of Kahn's buildings - an oversight that is particularly unfortunate when examining his institutional designs. As we know, Kahn was interested in the "existence will," the "spirit," of institutions, and how that spirit might be embodied in an architectural form (see [Kahn 1961, 1970]). We cannot forget that institutions are social constructions; they are, as Libero Andreotti says in his study of the Exeter library, "the social expressions of the order of human nature" [1984: 160]. We therefore have to wonder how Kahn realizes a "Form reflective of [the library's] order" - how he translates that Form into a design, a geometric assemblage, that represents "the accumulated wisdom [the library] stewards;...the spontaneous encounters it allows;...the needs of people who may, because of its presence, gain presence" [Andreotti 1984; Marlin 1973: 34]. What geometries express, and foster, the kinds of encounters and qualities of presence that define Library?

A few critics and scholars - particularly Andreotti, Jordy, Kohane, Scully, and Wickersham - have addressed the symbolic functions of the Library's geometric forms. I will reassess much of this literature through a rhetorical lens: I will revisit the Phillips Exeter Academy Library (which, since 1996, has been known as the Class of 1945 Library) as a rhetorical space, in the sense that, through its form and materiality, it argues for a pedagogy and an "existence will" that defines the library and the Academy as institutions. There is plenty of precedent for regarding architecture as a form of communication or rhetoric; anthropologist Edward T. Hall [1959] calls human spatial practices one of the "primary message systems" of culture, while semiotician Umberto Eco [1997] reads architecture as a system of signs, and McLuhan [1994] proposes that housing is a medium. Adrian Forty [2000] and Jonathan Hale [2000] identify several other architectural and communication theorists who regard architecture as a system of meaning or rhetoric. Kahn might have denied that his architecture had any rhetorical purpose; according to Goldhagen, "[h]e claimed that even his geometries, which in their Euclidean simplicity so invited symbolic interpretation, were abstract" [2001: 152]. "I 
use the square to begin my solutions because the square is a non-choice," he claimed (quoted in [Goldhagen 2001: 152]). Yet "the monumental imageability of Kahn's buildings, together with the public nature of the institutions they house," Goldhagen says, "nearly insist that members of a community appropriate them as symbols. They stand as physical embodiments of the social values ... that their institutions represent" [2001: 209]. Scully agrees: "The signs and symbols are certainly there in Kahn's buildings, all emphatically embodied in solid matter. They are intrinsic to the structural forms ..." [1989: 40].

The first and second sections of this essay will focus on the macro-scale exterior and interior geometric forms - the "packing crate" constructed of brick planes, the doughnut plan, and the circles, squares, and triangles defining the central hall. I examine how these forms function as a medium for "institutional rhetoric," defining the values of Phillips Exeter Academy and of the library as an institution. I aim in these two sections to address an over-emphasis in current scholarship on Kahn's personal design philosophy and his own relationship to architectural history - an emphasis that leads to a bracketing out of the institution's historical context. Much of this existing work ignores the relationship between Kahn's design and other libraries designed in the same time period, and it disregards the influence of Phillips Exeter Academy's (PEA) 200-year history and entrenched pedagogical mission on the purpose and program of its Academy library. Kahn's own professed disregard for the client's influence may foster a similar disregard within the scholarship on his work. He claimed that " $[t]$ here are few clients who can understand philosophically the institution they are creating," and thus the architect must take it upon himself to act as "philosopher for the client"; the architect must, as Jordy puts, it, "reconstitut[e] ...the programme in light of what the institution primarily is with respect to the cumulative human experience of using it" (quoted in [McCarter 2005: 223; Jordy 1974: 330]). While acknowledging the innovation of Kahn's design, we must also read through his conceit to appreciate the significant influence on the design of both the Academy's tradition, and the insightful and progressive library program created in 1966 by a PEA faculty committee.

The third section examines how the building houses the collection, and how Kahn's more micro-scaled architectural geometries and furnishings - and their connections to light - create a habitus that structures the way patrons interact with books and with the building. In order to examine visitors' experiences of these interior spaces, I draw on published letters from Exeter alums, many of who eventually served in the Friends of the Academy Library. I then look, in the fourth section, at how the building, which literally places "orality" at its core, in the form of a large, public central hall, integrates formal expressions of both literacy and orality. Drawing on the work of Walter Ong, I examine the place of orality and literacy in Exeter's signature pedagogies, and address how the library functions as a pedagogical space. Finally, in the fifth section, we look how the Library has accommodated the technologies of what Ong calls "secondary orality": how new media forms - film, video, audiocassettes, CDs, word processors, wirelessly networked computers - have been integrated into the library. Drawing on McLuhan's distinction between "light-on" and "light-through" media to address these media formats' varying relationships to light and their spatial demands, I examine whether Kahn's architectural geometry, which took the rectangular book as its module - and which made those books, displayed in linear stacks, its ornament - might resonate differently for a new generation of media and library users. 
Ultimately, analyzing the myriad rhetorical registers on which Kahn's library operates, we find several breaches - between media and architectural forms, between institutional ideologies and the ideologies embodied in material form. The building's timeless architectural form is rooted in the light of the Enlightenment - a light that is in no way diminished, but has, within the past several decades, been joined by other sources of illumination. The Library as a whole is based on the geometry of the book - a geometry that, in the end, is unable to represent the non-Euclidean nature of new media and the seeming disorder of nonlinear, networked modes of learning.

\section{The institutional rhetoric of the brick box}

The Phillips Exeter Academy was founded in 1781 by Dr. John Phillips, Harvard graduate and Exeter local, to teach its students "not only in the English and Latin grammar, writing, arithmetic, and those sciences wherein they are commonly taught, but more especially to learn them the great end and real business of living" - a way of life based on the belief that "goodness without knowledge is weak and feeble, yet knowledge without goodness is dangerous" [Phillips Exeter Academy, Academy Archives]. In 1930 a gift from oil magnate Edward S. Harkness provided for the implementation of a new pedagogy and pedagogical "architecture": the Harkness table. "What I have in mind," Harkness said, "is [a classroom] where [students] could sit around a table with a teacher who would talk with them and instruct them by a sort of tutorial or conference method, where [each student] would feel encouraged to speak up. This would be a real revolution in methods" [Phillips Exeter Academy, The History of Harkness Teaching]. The design of the table evolved until it comfortably fit a group of students, typically 12 , and their teacher, such that everyone was able to make eye contact with one another. "As the physical table itself implies, learning at Exeter is a cooperative enterprise in which the students and teacher work together as partners" [Phillips Exeter Academy, The Harkness Table]. Some of the original tables were too large to fit through the classroom's doorways, according to the Academy's website, so "builders brought their materials to the classrooms and constructed the tables inside. This means that Harkness Tables really are part of the rooms in which Exeter's community learns, teaches, discusses, and collaborates" [Phillips Exeter Academy, The History of Harkness Teaching].

The room, we might say, grows out from the table, its physical, pedagogical, and symbolic center. Harkness's vision thus shaped the institution's teaching and learning philosophies - philosophies that, in turn, impacted the arrangement and use of spaces in which teaching and learning were to take place, including the Library. In a 1984 letter to the Friends of the Academy Library, the group's secretary Robert N. Shapiro notes that "[i]t was the Harkness Plan in the 1930s that really changed the role of the Library at Exeter":

Recitations were no longer the norm, texts were no longer the only books used in class. Supplemental reading, independent research, short selections from many books held on reserve - all these brought students into the Library. Not surprisingly, the collections grew quickly, and soon displaced the English classes that had originally been held in the rooms on the first floor. A periodicals room was created, and across the hall the librarian's office. That, too, was eventually crowded with old and rare books, microform machines - and a model of the new library [Shapiro 1984c].

In the meantime, as these new technologies began appearing in the old Davis library, other curricular changes incited changes in the use of pedagogical space. In the 1950s, 
the history department began assigning more research papers, driving more students to the Library, which had made the once-closed stacks open to students [Shapiro, June 1985]. The geometric regularity of bookstacks, a newly inhabitable space, thus became a new spatial form shaping students' learning experiences. Exeter's pedagogy therefore had multiple geometric expressions: It was an oval table; it was the linear bookstacks; and, eventually, when Davis proved insufficient to handle these new patterns of use, it was Kahn's circle-in-a-square.

A committee composed of librarian Rodney Alexander, French teacher Elliott Fish, and history teacher Albert Ganley were charged with developing a program - "no more than a guide...[with] general proposals which might shape [the architect's] mental image" of the new library [Phillips Exeter Academy 1966: 1]. Most buildings on the campus are red brick, neo-Georgian structures, so the faculty committee asked that the library be made of brick, too, and that it be "unpretentious, though in a handsome, contemporary style" [Phillips Exeter Academy 1966: 2]. Yet Kahn, ultimately chosen for the project from among a list of prominent architects, claimed to design as if no library had existed before and as if the client's program was disposable. He seemed to take credit for the Library's brick exterior: "Brick was the most friendly material in this environment. I didn't want the library to be shockingly different in any way" (quoted in [Wiggins 1997: 12]). ${ }^{1}$ Regardless of where the idea originated, brick tied Kahn's new structure into its context aesthetically and symbolically, expressing traditional values, yet in a contemporary form.

There are five rows of openings in the building's brick facades: the openings at the ground level reveal a "deeply shadowed arcade" leading into the main entrance, while the top-level openings, framing views of the sky, partly obscure a rooftop terrace [McCarter 2005: 309]. ${ }^{2}$ In between, there are three rows of windows ringing the building, suggesting that these three floors, plus the ground level, make for a four-story structure. Yet each of those windows is double-height, and there are "shed-roofed mini-buildings" set back from the building perimeter on the upper level; thus, there are actually eight floors sitting above ground. Judging by fenestration alone, the building seems smaller than it actually is. Yet Annette LeCuyer notes that the facade's bricks are smaller than standard size, which makes the library appear larger than it actually is [1985: 76]. Kahn had planned to include stair towers at each corner of the building, but, for the final design, stripped those towers away to create re-entrant corners, and thereby "under[cut]... what might have been an off-putting monumentality" [Russell 1997: 94]. The cut-away corners reveal the full depth of the outer brick doughnut, which appears to be faced with freestanding screens detached from the concrete structure behind.

Beneath each of the large windows, recessed into the brick wall on floors one through three, are unfinished teak panels with a pair of tiny inset windows positioned flush with the wall. Behind each of these small windows is a pair of carrels, while the large windows above illuminate mezzanine-level carrels in the double-height arcades. These "different window patterns," Wickersham says, "temper the uniformity of the brick walls and offer the only clue to the different activities that take place within" [1989: 148]; we'll discuss these interior spaces later. Kohane notes that on one of Kahn's fenestration studies, a human figure was "used to fix the size and proportion of each fenestration unit"; this "body-centered approach" to design suggests that "the reader will always be sheltered within an architectural environment that is given intimacy and human warmth by proportional concordance with his own body" [1990: 117]. The teak panels, too, seemed a fitting representation of the intimate relationship between reader and book that was 
being cultivated at the individual carrels behind the panels. The windows are thus both literally and symbolically transparent; they are instructive about the library's internal layout, and their materials and scale link them to different qualities of activities inside.

In between those windows are brick piers that are equally instructive about their structural function. They become progressively narrower toward the top, as the load they bear decreases, and as the windows become wider. "Kahn intended that the inhabitant empathetically read the building's structure," McCarter says, by imagining through the changing widths how the piers are "dancing like angels" above and "grunting" from the weight down below [McCarter 2005: 309; Kahn, quoted in Brownlee and DeLong 1991: 355]. Wickersham refers explicitly to the exterior skin as "rhetorical": it is "used to dramatize the structural forces within the building" [1989: 147]. In addition to providing a "lesson on construction logic," the brick walls also serve rhetorically to convey in part the "spirit" of the library: Kohane argues that the narrowing piers suggest "a feeling of ascension that was surely relevant to Kahn's idea of the library as a place where readers strove to attain higher realms of knowledge" [LeCuyer 1985: 76; Kohane 1990: 118]. This transparent expression of structure, combined with the literal transparency of the windows, reflects the institution's mission to provide a sound education in which the ascension to enlightenment is rationally structured. In addition, the simultaneous application of maximizing and minimizing optical illusions plays on both the microsocial and the macrosocial roles of the library; fenestration and brick work together suggest that the institution within provides a learning environment for the individual as part of a community. Kohane agrees that Kahn, having thought about the nature of Library since his 1956 competition entry for the library at Washington University in St. Louis, acknowledged at Exeter the "importance of an individual's private and public life, the interconnections between each realm, and the relationship of both to a spiritual existence" [1990: 99].

Instead of being sited at the center of campus - a position that would have reinforced the importance of structural logic and the ascension "spirit" to the Academy's identity and mission - the library sits along the side of the quad, "protruding into the green space without respect for the existing building line ... Thus, the library - like a boulder in a stream - disrupts the movement of students along the edges of the quad, forcing them to walk around the structure and drawing them into the ground floor colonnade" [LuCuyer 1985: 76]. One can enter the shady brick arcade from any direction - "[f]rom all sides ... there is an entrance," Kahn said (quoted in [Wurman 1986: 178]) - but depending on what direction that is, he or she might have to circle the building to find the entrance, a glass vestibule on the north side of the building. "Perverse as the hidden entrance may seem," Jordy acknowledges, "it emphatically reinforces Kahn's statement that his design begins on the periphery ..." [1974: 333]. We might read this entrance sequence as a symbolic rite-of-passage to enlightenment - which seems to be how Peter Greer, Exeter alum, experienced it. In a January 1991 letter to the Friends of the Academy Library, he recalled what it felt like to approach the building:

As I walk up the path toward the north-east corner of that building, I saw again what I love to see: that even as it soars over me, diminishing me in a sense, I see myself reflected in the corner window, and my reflection, of course, grows larger as I come closer. That growing reflection suggests to me that the Library, far from something that diminishes me, is nothing more than a reflection of my own potential for intellectual and cultural growth [Greer 1991]. 
Although we might find within the play of scale, transparency, and structural rationalism of the facade a generally coherent rhetoric conveying the core values of Library and School, we will soon see that there is a physical and rhetorical breach between this façade and what awaits us inside.

\section{Circle, square, seduction, and ceremony}

Once the visitor has located the glass vestibule, he walks through the door to find a rather pedestrian message board with announcements of upcoming Academy events and two display cases angled to direct one toward a glass entrance into the ground-level Periodicals Rooms. Yet, on an initial visit to the library, one rarely notices these quotidian elements. Instead, the visitor's eye and body are drawn toward a grand double circular staircase whose "ceremonial function is explicitly denoted by its white travertine marble facing" [Kohane 1990: 110]. As the visitor approaches and climbs the stair to the central hall (fig. 1), one flight up, massive concrete beams obscure his view.

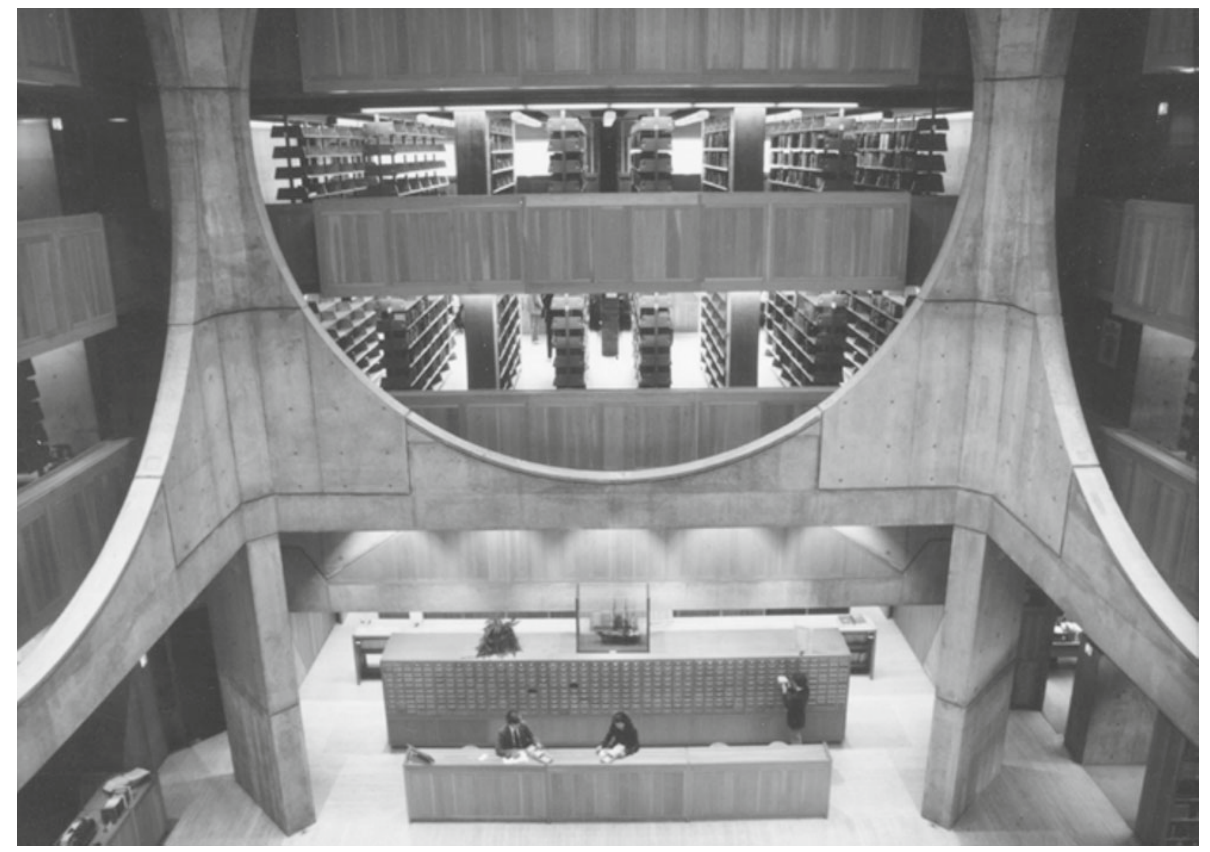

Fig. 1. Rockefeller Hall. Photo courtesy of Dennis Waters

This "gradual unfolding of the central space creates a strong sense of anticipation" for the ascent "into the realm of ideas" [Kohane 1990: 112]. "Having traversed the intricate entrance sequence, one responds with all the more intensity to the perfectly ordered geometries of the light-filled hall" [Kohane 1990: 110]. Kahn likely borrowed this idea of a large central space, which was not called for in the library program, from seventeenth-, eighteenth-, and nineteenth-century libraries, which used the central hall to "impress upon the reader the accumulated knowledge of centuries available for study. ... It is a place to pause, to reflect upon the knowledge, history, and tradition embedded in the books" [Jordy 1974]. Kahn's central hall, a monumental room rising the full height of the building, is likewise where one receives the "invitation of books." Much has been made of the centrality of the book to Kahn's design; he regarded the book as "an offering 
of the mind," and the library "tells you of this offering" (Kahn, quoted in [Wurman 1986: 202]). He saw the library as a "place where the librarian can lay out the books, open especially to selected pages to seduce the readers" (Kahn, quoted in [Brownlee and DeLong 1991: 309]). As Glenn Wiggins suggests, the Library itself "participates in [this] seduction of the user"; the building functions rhetorically to entice the reader to "take the books and go to the light" [Wiggins 1997: 16].

Large circular openings in the walls of ceremonial Rockefeller Hall, reminiscent of Kahn's Bangladesh National Capital at Dhaka, stretch so that their 30-foot diameter is roughly the full width of the wall, suggesting that their purpose is not to provide mere "glimpses" of the books behind, but rather to envelop the collection and tie the stacks and the communal space of the central hall together into a comprehensive expression of "Library spirit." It is what Kahn might call an "architecture of connection." The circles serve as windows onto a landscape of knowledge, and the concrete forms themselves represent the order and stability of that body of knowledge, and of the library's and the Academy's tradition. At the American Institute of Architects' 1997 conference, where the library received the AIA's 25 Year Award, a panelist called the library's geometry "tough and thoroughly humane" [Shapiro 1997]. Just a few years before, Sally Murray James, an Exeter alumnus, recalled her experience of the space in similar terms:

The huge concrete forms of the inner space continued their endless, weighty round of tic-tac toe. The quick interplay of spaces perpetually celebrated the sheer joy of learning, rather than the mere heft of work. The infinite views up, down, across, around, and through the building remind me that persistent curiosity yields answers far beyond the questions we have thought to ask [James 1993].

Yet it is significant that Kahn chose to detach the walls of the central hall from the adjacent floors in the concentric concrete "doughnut"; the circle and square volumes defining the boundaries of Rockefeller Hall are freestanding - seeming, like the building's external brick façade, to float away from its external volumes (fig. 2). McCarter explains that "Kahn conceived of these three types of spaces [the central hall, the stacks, and the perimeter reading spaces] as if they were three buildings, constructed of different materials and at different scales, buildings-within-buildings" [2005: 306]. The separation of the outer ring of carrels from the concrete ring of bookstacks symbolically distances these functions: book storage and reading. The distance between the central hall's concrete volume (which was, at an earlier stage in the design, to be made of brick) and the oak-clad terraces and metal stacks beyond, seems to emphasize the central hall's framing of the bookstacks. Kohane and Gast suggest, tellingly, that the circular frames present the books as "the ornament of the interior," as the building's "treasure" [Kohane 1990: 110; Gast 1999: 132]. Kahn puts the books on display, but at the same time protects them behind concrete from damaging sunlight. What is the significance, though, of presenting books as both the library's currency and its treasure - both as something to be used, and something to be displayed? How do we reconcile this "exhibition" of books with the library program's declaration that "the emphasis should not be on housing books but on housing readers using books"? [Phillips Exeter Academy 1966: 6]. 


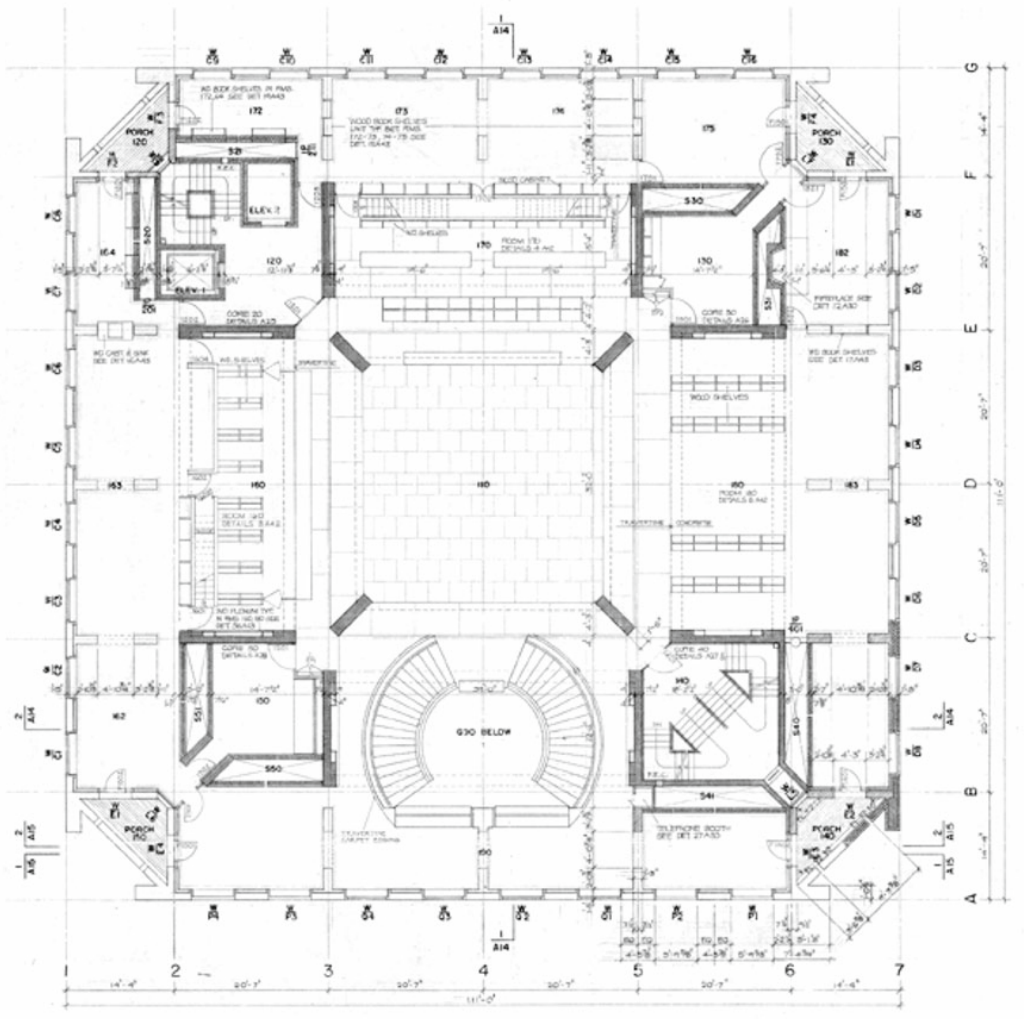

Fig. 2. Detail of plan of first floor. Louis I. Kahn Collection, University of Pennsylvania and the Pennsylvania Historical and Museum Commission

Several critics have addressed the rhetorical functions of Rockefeller Hall's geometric forms and their material realization. Jordy examines how the "semi-circle of the entrance stair, set off as a geometrical shape by its travertine lining against the concrete finishes all around, ... plays with the circles in elevation," and how "this circularity alternates with the angularity of the stack-supporting girders" [1974: 334]. He regards these geometric systems as "architectonic supergraphics," perhaps communicating the structural integrity of the hall and demonstrating how it is to be used and what qualities of presence it fosters. Goldhagen argues that through these formal graphics, "highly abstracted allusions to historic monuments," Kahn "encourages a community to transform a building from a landmark into what he called a 'people mark,' an architectural vehicle that situates people in their community" [2001: 209]. For Wickersham, the library's rhetorical structures get at the "spirit" of the institution: they "dramatize the nature of the library as a storehouse of learning, and...provide a central focus for the Academy's campus" [1989: 141; italics mine]. The Library committee, of course, recognized this representative potential, too:

The quality of a library, by inspiring superior faculty and attracting superior students, determines the effectiveness of a school. No longer a mere depository of books and periodicals, the modern library becomes a laboratory for research and experimentation, a quiet retreat for study, reading and reflection, the intellectual center of the community [Phillips Exeter Academy 1966: 1]. 
Gast sees in the floorplan the "Indian image of contemplation," the mandala [Gast 1999: 132], while Andreotti finds that the "centrality and symmetry" of Kahn's design represents the library as "a public institution, symbol of the life of the mind" [Andreotti 1984: 162]. Yet according to Jordy, some critics find fault with the "rhetorical flourish of the central space," for its extravagance [1974: 335; italics mine]. Goldhagen suggests that, "instead of seeing in the library at Exeter idealist geometries recalling past architectural traditions, one could better...contemplate the social vision implied in placing a grand and richly detailed common space at the heart of building where privileged teenagers come to do their math" [2001: 2]. Rather than being taken in by the mystical Kahnian theories of timeless, universal symbols and institutional "existence wills," one might consider how Kahn's rhetorical forms function within Exeter's particular socioeconomic context. $^{3}$

Light also plays a symbolic role here. In Rockefeller Hall, light shines from overhead through clerestory windows and past two concrete beams that intersect to form a large "X." These cross beams tie together the four walls and add another geometric form - the triangle - to the circle and square. According to Wickersham, the beams serve only a limited structural function, but they are "essential to the visual stability" of the central hall, and they "act as a baffle, to screen and diffuse the light" entering through the overhead windows [1989: 145]. These different qualities and intensities of light represent the different forms of learning, different stages of knowledge acquisition, that Kahn found integral to the library's meaning. Wickersham explains:

At Exeter, Kahn distinguished between the direct "white light" which streams in through the windows onto the study carrels and tables, and the indirect "blue light" which filters down from the top of the central hall. Just as the physical display of the books in the bookstacks is meant to dramatize the library's nature as a storehouse of knowledge, so in Kahn's mind the descent of the blue light dramatizes the student's encounter with knowledge and truth - not in the collective setting of a classroom, but as an individual, who would set foot in the hall alone [1989: 142].

\section{Geometries of books and reading spaces}

After the visitor accepts the "invitation of books" and moves into the stacks (fig. 3), he maintains contact with the central hall through continuous balconies overlooking the hall. Each balcony features an oak bookshelf around the central perimeter. The shelves offer inclined surfaces for the display or perusal of books, "allow[ing] readers to be at once in the stacks, separated, and also to be brought together around the central room" [McCarter 2005: 316]. The central hall thus functions as an "architecture of connection" from both on the ground and up in the stacks. The stacks, by the way, are standard institutional metal shelves, with a capacity for 250,000 volumes, and are lit by fluorescent lights, although daylight from the large exterior windows and the clerestory windows does reach this area.

After selecting his materials from the stacks, the reader then moves toward the study areas along the building's perimeter (fig. 3), toward "the more prosaic white light" [Wickersham 1090: 142], where he finds a band of two-story high brick arcades circling the building. This is where we see the large windows that clouded our judgment of the building's exterior scale. These windows provide light for the interior reading areas and mezzanine-level study carrels. Light is of course a central metaphor in Kahn's designs, but here in the library it is critical both symbolically and functionally. Architect Brook 
Muller suggests that Kahn's "patterns of spatio-luminous organization" at Exeter represent more than just a "high modernist's deployment of an enlightenment notion of humankind's privileged access to the light of knowledge" [2008: 189]. A more "experiential interpretation" of enlightenment acknowledges that finding and reading books are activities "'threaded with'...tactility, view, footfall, passage, etc. Knowledge is a journey and light calls forward" [Muller 2008: 189]. We saw how "passage" into the building and central hall informed the rhetoric and process of "enlightenment"; we will now examine how enlightenment is embodied in the library's book storage and reading spaces.

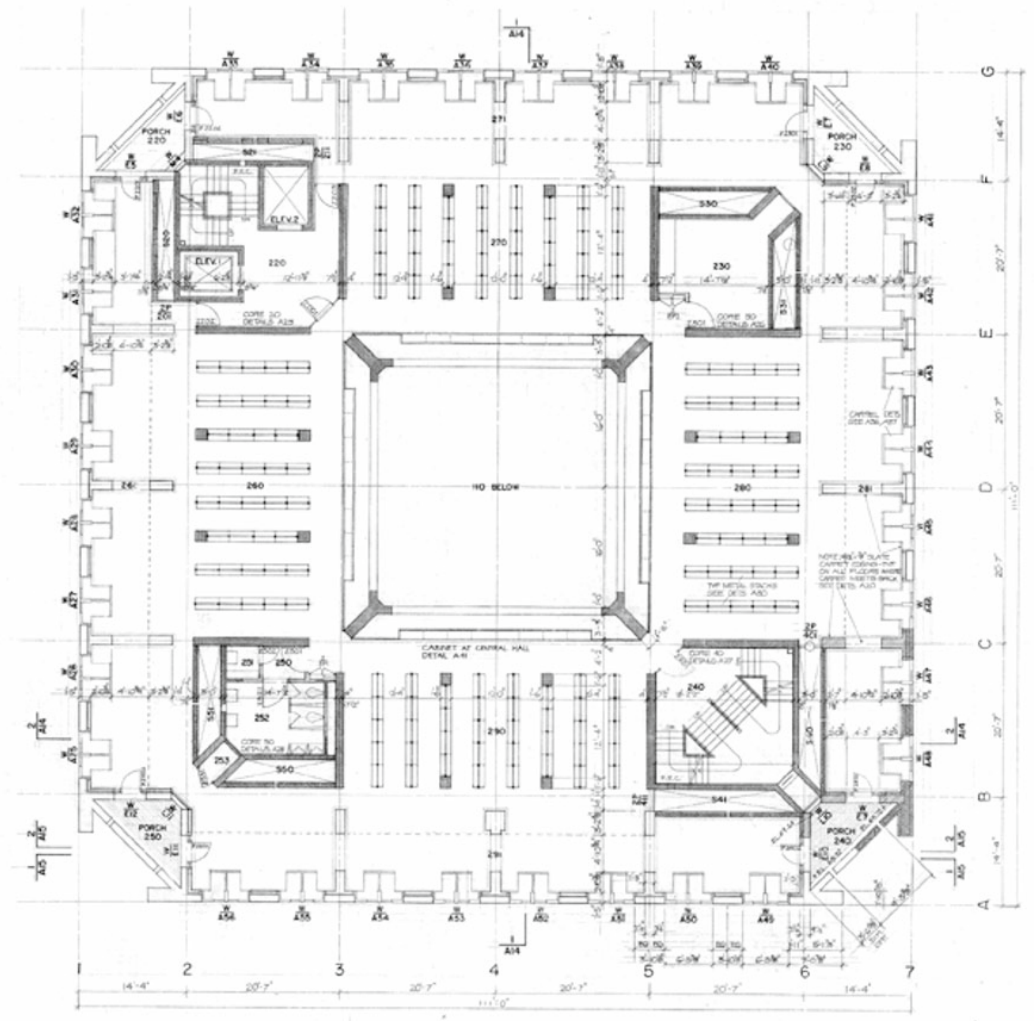

Fig. 3. Detail of plan of second floor. Louis I. Kahn Collection, University of Pennsylvania and the Pennsylvania Historical and Museum Commission

The arcades mark the transition to a new stage of knowledge acquisition - a stage physically separated from the selection of reading material: the act of reading itself. Kahn was inspired by the organization of medieval libraries as described in Russell Sturgis's $A$ Dictionary of Architecture and Buildings; in his essay "Space Form Use" Kahn references Sturgis's description of the library at Durham, with its windowed carrels that "grew out of the monk's desire to read and learn" [Kohane 1990: 105]. This spatial organization of the monastic library was later discarded in favor of the "rational separation of functions" [Kohane 1990: 130].

A space order for a library which encompasses many possible relationships between books, people and services could possess a universal quality of 
adjusting to changing human needs, translatable into an architecture. A library designed around the incipient influences of standardized book storage and reading devices could lead to a form with two distinct space characteristics - one for people, one for books. Books and the reader do not relate in a static way [Kahn 1965: 43].

Kahn proposed that at Exeter he would give new shape to the fundamental desires of reading and learning. McCarter commends Kahn's "literal inversion of the traditional library programme and plan type" by turning inside out "the habitual separation of the central reading room from the peripheral book stacks"; placing the reading rooms, in the form of carrels, at the periphery; and keeping the books "within, protected from the natural light" [McCarter 2005: 306]. Kahn maintains the majestic central space, which in libraries of the late nineteenth and early twentieth centuries served as the grand reading room, but here he dedicates it to social exchange, and provides alternative reading spaces that "recogniz[e] the...changed - more private - relationship between reader and book" [Andreotti 1984: 162] (fig. 4). Kahn may have come to his realization of this "changed relationship" independently - but the library committee also called in their 1966 program for a building that provided both "areas for creative independent study and for easy social exchange of ideas" [Phillips Exeter Academy 1966: 1-2].

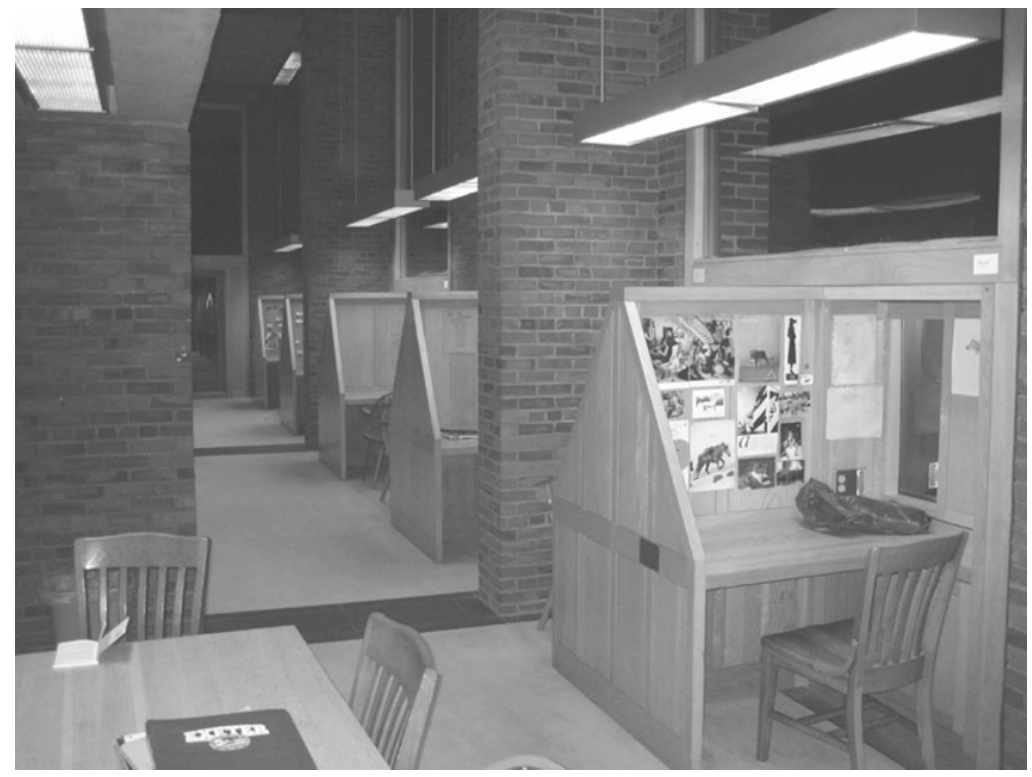

Fig. 4. Student carrels. Photo by the author

The program stated that "carrels should be of wood..., high enough to afford a sense of privacy," that they "should be arranged in alcoves around the book stacks,...near windows for enjoyment of natural light in a pleasant view," and that they should include locking cabinets for storage [Phillips Exeter Academy 1966: 7]. And this is precisely what Kahn provided. Each of the perimeter study carrels features a locking cabinet below, a triangular "privacy" screen, and a tiny rectangular window that offers a view outdoors because, as Kahn recognized, "occasional distraction is as important in reading as concentration" (quoted in [Jordy 1974: 334]). Sally Murray James describes how the carrel's geometry and materiality shaped her experience: 
My nook was exactly the magical, private world Kahn had intended. The comforting brick wall. The warm, light wood. The sliding shutter on the window to vary the width of possible distraction. The cabinet under the window, which locked. The generous triangle of wood running interference between studies at hand and the nearby stacks [James 1993]. ${ }^{4}$

Muller also acknowledges how the "specific configuration of built-in furnishings from shelves to desks carefully choreographed with the natural light and registered closely with the human body become a primary source of architectural expression/celebration" [2008: 189]. The geometric forms of the carrels, chairs, shelves, wall panels, and the materials of which they are made, inform the private study experience. We can contrast the warm, textured materials - the wood, carpet, travertine, and brick - of what Kahn called the "served" spaces - the central hall, the reading arcades - with the utilitarian materials slate floors, metal bookstacks and doors, fluorescent light bulbs - of "servant" spaces like the stacks and stairwells [Wickersham 1989: 147]. This is Kahn's material rhetoric, using materials to denote and connote different spaces in the Library.

The Library's program called for "a number of choices as to chairs, tables, light and temperature," and suggested that in some areas the surroundings be "as inviting and pleasant as those of a literary club" - although, throughout, the interior design was to "assure and protect...dignity, distinction, and individuality" [Phillips Exeter Academy 1966: 6, 8-9, 11]. The scale in the arcades is more intimate than elsewhere, and the mood a bit more domestic, too. White oak panels, Oriental carpets, paintings and sculptures, and model ships enhance the anti-institutional ambiance. In addition to the carrels, the region beyond the stacks offers enclosed rooms, large tables, and "homesaway-from-home" reading areas with sofas and armchairs grouped around fireplaces and windows [LeCuyer 1985: 77]. The variety of study areas that Kahn ultimately provided reflects his sensitivity to the diverse "modes" of study: a comfy couch and a fire for an engrossing novel; a rigid chair and large table to spread out materials for a research project; a private room for group recitations of a play.

Kohane explains how the arcades' brickwork reflects Kahn's appreciation for the psychology of reading - and, consequently, creates an atmosphere conducive to study. The masonry, he says "delineates individual bays, which interact with the natural light to provide the intimacy needed for the isolated and passive act of reading" [Kohane 1990:114]. Kahn refers to these bays as "discovered place[s] in the folds of construction" (quoted in [Architectural Forum 1972: 77]). Even the books in the stacks reinforce the arcades' peaceful ambiance by providing a "visual and acoustic barrier" to the public central hall [Kohane 1990: 114]. Furthermore, the stacks "thwart the potential panopticon of the central plan"; because they stand between the librarians in the central hall and the students in the outer regions, the librarians have only limited means of surveillance [Kohane 1990: 114]. This sense of "reading autonomy" bespeaks a much different relationship between reader and book than that represented in the early twentieth-century libraries, with their great halls under careful surveillance, and the medieval libraries, with their books chained to desks. Exeter offers a much freer, less controlled, more personally directed learning experience.

The library's geometry and materiality permit and prohibit various visual perspectives, thereby serving to define the politics of reading and learning, and, by extension, of the institution that provides these opportunities. The 1966 library program addressed the hierarchical relationship between librarian and patron by recommending 
that the circulation desk be situated at the library's "working center" in order to foster "meaningful encounters between student and specialist in the creative use of books"; the committee realized that their recommendation "differ[ed] from current practice," in which the desk is placed near major entrances so the librarian can oversee patrons' activity throughout the building [Phillips Exeter Academy 1966: 13]. But their proposal "ensured that service took priority over supervision" [Phillips Exeter Academy, Design of the Library]. Shapiro declares to the library Friends that the building's form and function "rest on a fundamental trust": "There are no gates or barriers. The circulation is on the second level. No one is stationed at the doors. The building respects it patrons" [2002]. Annette LeCuyer reports that Jacqueline Thomas, Academy Librarian, "attributes the overall lack of disciplinary problems to both the caliber of students and Kahn's design" [1985: 77]. A panelist at the AIA convention celebrating the library's 25 Year Award also suggested that Kahn's design, with its geometric volumes, functions rhetorically to promote fitting behavior: "The space educates and makes you thoughtful, it is quiet not because of isolation and intimidation but because the open central space calms you down and connects you with everyone and everyplace in the building..." (quoted in [Shapiro 1997]).

Yet librarian Jacqueline Thomas told me a slightly different story. When the building first opened, she said, the students - mostly boys, since the library had become co-ed only in 1970, and there were still relatively few girls there in 1971 - "didn't know how to use the building. They weren't used to all those floors and all that freedom" [Thomas 2009]. The openness, the massive volumes, the placement of students in visually prominent places, where they could look down on staff from the balconies - these factors confused students' normal codes of behavior and thus, Thomas surmises, led to some misbehavior [Thomas 2009]. Sally Murray James recalls: "The architect had a son about my age.... I don't know whether Kahn ever imagined the boy as a student at the school, making light of the building, as students do - launching paper airplanes from the mezzanines or leaning into the central space to hail a friend four floors down" [James 1993]. Archivist Ed Desrochers also recollected the problem of "interfloor communication" [2009] between students on the mezzanine and main floor carrels, which is why the librarians now seem to discourage use of the mezzanine carrels. I saw few occupied during my visit.

The architectural geometry itself thus seems not to be sufficient in suggesting appropriate behavior and disciplining students. The Library provides a habitus, which Bourdieu defines as a system of "durable, transposable dispositions, structured structures predisposed to function as structuring structures" [Bourdieu 1972: 72]. These "structuring structures," rather than prescribing or dictating behavior in particular settings or situations, merely shape predispositions that are more embodied, internalized, than conscious (see [Dovey 2005 and Mattern 2007]). The habitus creates a field of "possibles" of potential behavior - and, as Shapiro [2002] notes, "[s]tudents have major responsibility there" to shape those potentials. "Each year, a group of senior day students is selected [as proctors] to help maintain smooth functioning and effective management" of the library [Shapiro 2002]. The proctors work from their own carrels and supervise students working around them, calming and shushing when necessary. I attended a preSpring 2009 term planning meeting during which several proctors discussed strategies for handling a group of "uppers" who regularly held loud conversations about subjects that "aren't appropriate for the library." "Students take care of students," librarian Thomas told me, and as a result, "they really feel the building is their own" [2009]. Thus, when 
the building's formal rhetoric alone fails to elicit fitting behavior from its inhabitants, librarians' and proctors' modeled behavior and instruction provide verbal and performative support for appropriate codes of behavior. The normal functioning of these reading spaces, these zones of literacy, thus relies in part on orality.

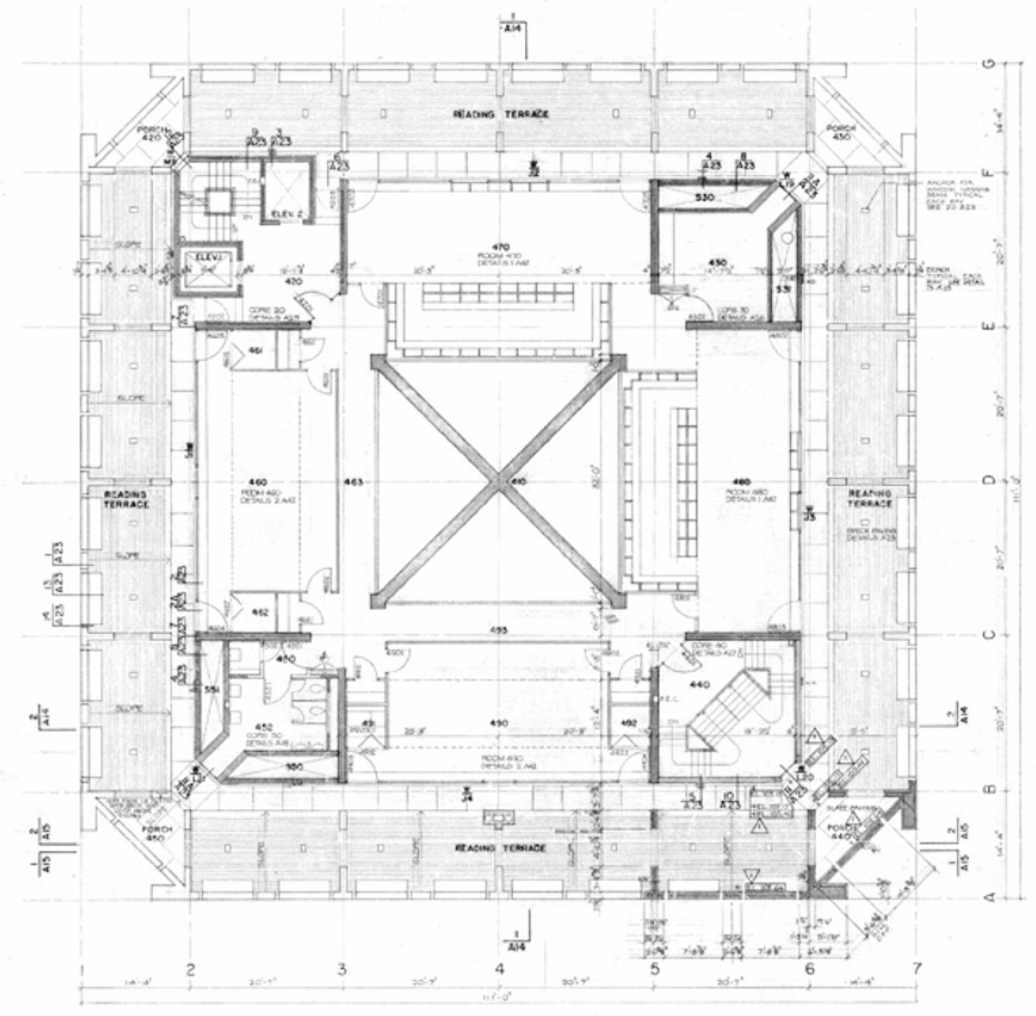

Fig. 5. Detail of plan of fourth floor. Louis I. Kahn Collection, University of Pennsylvania and the Pennsylvania Historical and Museum Commission

Before moving on to look more closely at how orality informed the library design, I will briefly address how other non-book print forms are accommodated in the building. In Kahn's original design for the library he positioned the "special areas" - periodicals, fiction, and rare books, among others - on the first floor; we might say that placing these collections in the central hall implies their centrality to the collection and to the mission of the Library. The committee, though, urged Kahn to move the periodicals to the ground floor, accessible beneath the grand circular stair leading up to Rockefeller Hall. The Library program had recommended that the periodicals room "be immediately accessible by location on the ground floor, since a librarian would customarily be in charge of this room at all times" [Phillips Exeter Academy 166: 22]. Even if the placement of periodicals on the ground floor is dictated by demand and the need for supervision, its position beneath the central hall and the stacks is indeed symbolically significant; it implies a subordinate, or at least "other," status. Fiction also moved up to the third floor, and the seminar rooms and rare book collection to the fourth, suggesting perhaps that these spaces will be in low demand, or perhaps in the case of the special 
collections, that they represent the highest level of ascension toward enlightenment (fig. 5). 5 The two seminar rooms are typically used for the administration's events and occasional classes, but Thomas says that "a few upperclassmen discover these rooms" [2009] and the nearby rare book rooms, after having never ventured up to the fourth floor in their first year or two at the school, and make them their new study bases.

\section{Geometries of rhetoric and pedagogy}

Oral rhetoric has a long history at Exeter. Golden Branch, a library and debate society founded in 1818, is believed to be the oldest secondary school society in the country. Today's students must take three years of any language, ancient or modern, to earn their diplomas. And the Library literally places rhetoric, orality, at its core. Rockefeller Hall not only expresses the "invitation of books," but it also represents the library as a "space for social exchange" [Andreotti 1984: 162]. "Literacy, a relatively recent human invention," Kohane explains, echoing Walter Ong [1982], "could not alone define the meaning of a building devoted to learning, since it developed within an existing oral culture" [Kohane 1990: 130]. So "Kahn devoted the grandest space to this earlier form of communication. Orality, with its accompanying facial expressions, gestures, and vocal inflections," Kohane says, mirroring (a bit too closely) Ong's language, "complements literacy, creating a connection between two activities necessary for a full realization of human capacities" [Kohane 1990: 130]. We see formal expressions of both orality and literacy, as Ong describes them, in Kahn's design: Ong characterizes thought and expression in oral cultures as additive, rather than subordinate; redundant; and conservative, in order to enhance its memorability. There are formal parallels in Kahn's repetition of basic geometric patterns, which build concentrically upon one another, rather than relating in complex syntaxes. Conversely, print, Ong argues, suggests that "words are things," and its fixity - of words on the page, of the sequence of pages in the codex - conveys the importance of "control of space" and rhetorical "closure" [Ong 1982: 118, 121]. Rockefeller Hall performs parallel rhetorical functions, controlling our vision of the books, which are framed by rigid geometrical forms; this enveloping frame connotes totality, closure, of the landscape of knowledge.

Rockefeller Hall is a mix of the oral and literate - a blending appropriate for a contemporary culture defined by what Ong calls "secondary orality," a "more deliberate and self-conscious orality" [Ong 1982: 136]. Kahn did not intend for Rockefeller Hall to function like the grand central reading rooms one finds in late nineteenth- and early twentieth-century libraries because, as he puts it, "everybody knows that a big reading room is only a place where boy meets girl" (quoted in [Andreotti 1984: 162]). ${ }^{6}$ This is not the place for coy chatter. This space is reserved instead for a particular kind of orality and performance: that which is formal, sanctioned, controlled - such as that between a librarian and student, or during one of the planned readings, concerts, film festivals, or receptions that take place in Rockefeller Hall (fig. 6). Furthermore, the volumes and materials of the central hall lead one to presume that any utterance louder than a whisper will reverberate throughout the building; the space thus incorporates its own material form of acoustic discipline. Yet the habitus is quite different in the stacks. During my visit a small group of boys congregated in the third-floor stacks to discuss everything but books, and their conversation was distinctly audible throughout the central hall. Kahn recognized that "in a small room one does not say what one would in a large room" - but those "structuring [acoustic] structures" are muddled when the small room spills out into the large (quoted in [Kohane 1990: 101]). 


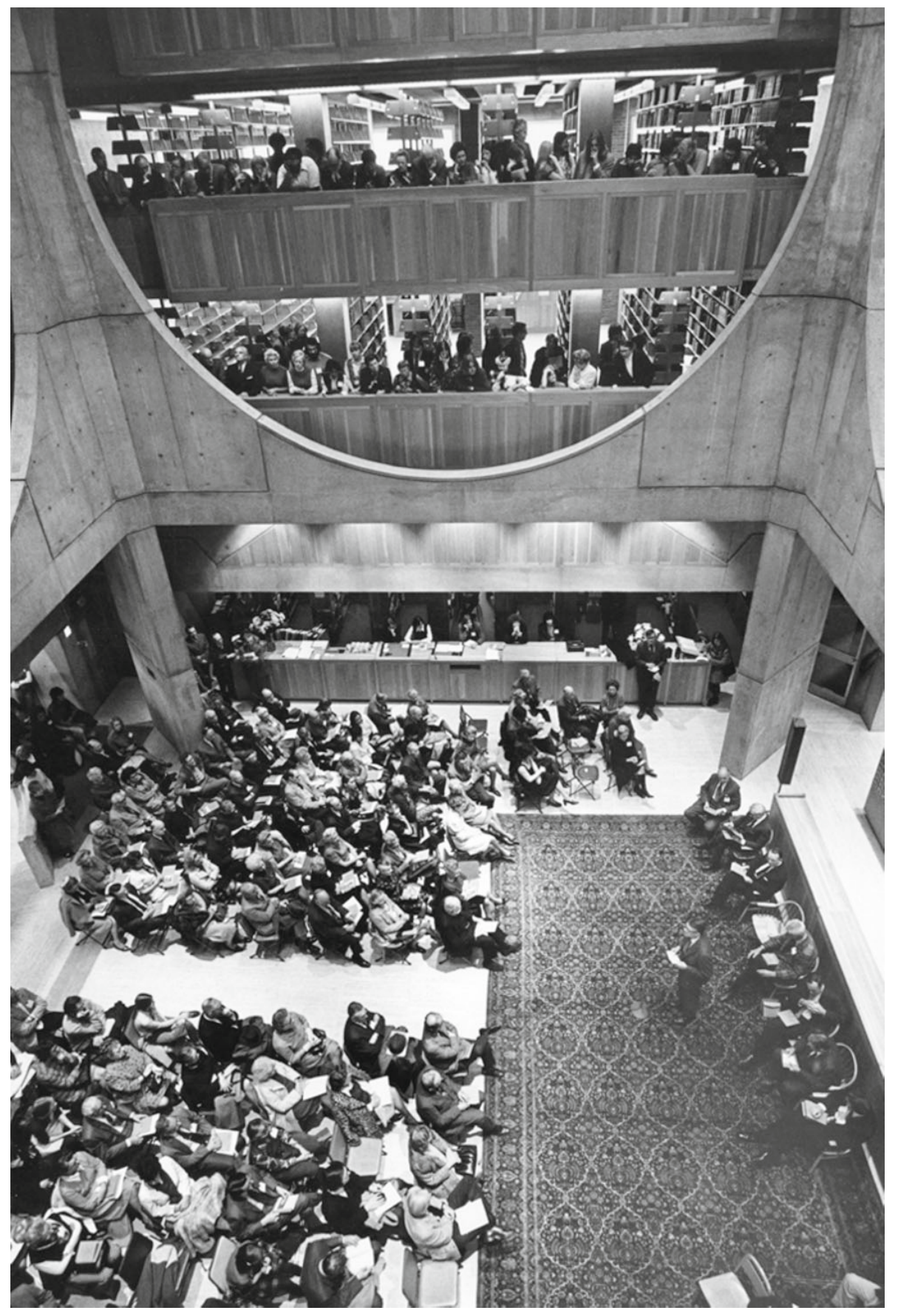

Fig. 6. Event in Rockefeller Hall. Photo courtesy of Bradford E. Herzog 
As we discussed earlier, Harkness pedagogy, a method rooted in disciplined orality, is embodied in the Library's form. The rhetorical resonance of Kahn's geometry was reaffirmed in 1985, when Exeter again implemented curricular changes that emphasized Library use. A new Junior Studies course, taught by librarians and instructors from a variety of subjects, and required of all ninth-graders - called juniors, or "preps," in PEA parlance - would "acquaint [students] with the entire library as a place of rich and varied learning" [Shapiro 1986] and introduce them to the "foundations of good scholarship" [Greer 1999]. In letter to the Library Friends, Shapiro describes the scene of thirteen teachers modeling a Harkness discussion for new students in the Periodicals Room:

For these [faculty playing students] from seven different departments housed in four buildings, no space could have been more suitable. The Library is, after all, Phillips Exeter's only building that is undeniably interdisciplinary. What better place for a demonstration of the pedagogical method that does more than anything else to connect the disciplines... [Shapiro 1992].

The Library, as the program committee had hoped, has become a "laboratory for (pedagogical) research and experimentation" [Phillips Exeter Academy 1966: 1]. The Library's form - with Rockefeller Hall's circle cut-outs framing and tying together the stacks of books across all subjects - both physically and symbolically integrates the disciplines, and indeed makes this space a curricular "architecture of connection."

The curricular changes of the mid-1980s made the Library central to the Uppers' (eleventh graders') curriculum, too. The eleventh-grade American history term paper has "become a rite of passage at Exeter" [Shapiro 1986]. Shapiro describes the project to the Friends:

The end of the winter term, in late February and early March, brings virtually all the Uppers to the Library, as every one of the 22 sections in the U.S. History course comes in for at least one class. As the first stage in the legendary American history term paper, the librarians introduce the students to strategies for starting research. Jackie Thomas starts by describing the many encyclopedias in the reference collection, bibliographies and special reference works. She reminds each class how to use the card catalog to identify subject headings relevant to the paper topics, and explains the Dewey decimal system.... Ed Desrochers, the Assistant Librarian and Academy Archivist, then introduces the students to the periodicals collection and the Readers' Guide, and talks about the resources available on microforms [Shapiro 1991].

Although we can assume that students are now learning more about electronic databases, and are using the online catalog rather than a card catalog, there is still a spatial and temporal structure to the eleventh grade year, with each term associated with particular media forms and particular spaces within the Library.

The Library, as we have seen, has a formal structure that is intended, in part, to instruct visitors about its construction and use, and to argue for a particular definition of Library. Kahn employs various material and formal rhetorical tropes to serve these didactic and persuasive functions. Andreotti argues that Kahn's translation of Form into 
Design relied on a language of “'orders' of space, light, structure, materials, and construction. Each 'order' poses its own demands”. For example:

The order of light demands that the choice of lighting be consistent with the building's formal characteristics.... The order of construction demands that the building reveal "how it is made."... Through the process of design, all these orders must be synchronically realized in ways that reinforce and make concrete the building's Form [Andreotti 1984: 161].

In regard to the order of "construction," Kahn was known as a practitioner of structural rationalism, who held that the building was to expose the "marks of its making" and serve as a "record of its creation" [McCarter 2005: 303]. "The materials of construction were to be honored, always to be left exposed" [McCarter 2005: 452]. The brick piers on the façade displayed how they bore weight, while the beams in Rockefeller Hall displayed the logic of the space's construction. However, Goldhagen argues that the ' $\mathrm{X}$ ' beam is "grossly exaggerated for dramatic effect" [2001: 3]. Structure is thus occasionally exaggerated or otherwise manipulated for rhetorical purposes.

Integrating the orders of materials and construction, Kahn believed that "the only ornament appropriate to modern building" [McCarter 2005: 452] began with the joint the meeting of construction materials. Where in the library does brick meet concrete, or glass, or teak - and what "constructional truth" or larger institutional truth about the nature of the library, is revealed trough this meeting? [Wickersham 1989: 147]. At the macro scale, we might also look at the rhetorical function of the joints between the library's three "doughnuts," or zones of activity. These zones, as we have seen, were differentiated by building material, scale, ambiance, etc. While Kahn employed reinforced concrete in the central hall, he chose brick for the periphery. While he chose a monumental scale in the central hall, he built on a more human scale in the periphery. These architectonic and material differentiations denote a differentiation between these three functions of the library institution. Kahn drew a clear distinction between the central hall and the bookstacks; their floors are not contiguous, and in order to access one from the other, one must retreat to the building's perimeter, to the elevator or one of the corner stairwells. By separating these spaces physically Kahn distinguished them, yet a continuous concrete floor slab connects the book stacks and the reading arcades, providing functional and experiential continuity.

Jordy prefers to address Kahn's architectural rhetoric through the "degree to which his method of work was ideally calculated to maximize meaning at various levels of reference": the level of functional use; the level of structural syntax (e.g., the crossbeams, the circle-in-a-square design); and the ceremonial extrapolation of the syntax (e.g., the meaning embodied in the central hall) [1974: 335]. According to Jordy, these levels often fail to reinforce each other; the three levels represent disparate understandings of the library form and of the meaning of the institution itself. We see the separation of the central hall from the book stacks, and the circular cutouts presenting the books as the library's "ornament," when the emphasis was to be "not ... on housing books but on housing readers using books." We also find rhetorical inconsistency in the exterior and the approach to the building. Some critics are perturbed by the circuitous entrance. Cesar Pelli complains that “There are certain things that are consistently unresolved in Kahn's work: I can never find the main entrance in his buildings. I find his buildings to be more about themselves than about the people who have to live with them ..." (quoted in [Kawasaki 1983: 216]). According to Michael Graves, Kahn was a self-professed Classical 
architect, and "[f] or a classical architect there is a sense that the face of the building is not only a reflection of the plan that it holds but also a reflection of the foreground plan that we are entering against. And Lou Kahn seems to be quite comfortable obviating that very substantial aspect of classicism..." (quoted in [Kawasaki 1983: 219]). Kohane, like Graves, faults Kahn's rhetorical façade; he regards as a mistake Kahn's "concealing such an important space (the central hall) behind the building's brick peripheral doughnut; the design "denies an external representation of the public sphere" within [1990: 129]. If the interior is to provide an "invitation [to] the books," why should the exterior be so uninviting? "[T] he exterior wall," Jordy argues, "remains substantially that - exterior to (parenthetical to) the idea of 'library"' [1974: 335]. Kahn originally intended to mark the entrance with a brick and granite plaza surrounded by stone benches and a hedge, yet these features were eliminated for budgetary reasons. The plaza was to have been a "first invitation" to the building and an external echo of one of the library's key internal functions: providing a place to meet [Kohane 1990: 110]. Thus, while we might try to rationalize, or find cohesion among, these recalcitrant aspects of the design - its breaking the geometry of the quad, its indeterminate scale, its perplexing entrance - we must also remember that Kahn had intended to clarify the logic and "spirit" of the transition between external and internal spaces. The budget foiled his plans.

\section{Media forms and architectural geometries}

When Academy Librarian and program committee member Rodney Armstrong left Exeter shortly after Kahn's building opened to become the librarian of the Boston Atheneum, architecture critic Ada Louise Huxtable described the Library - Armstrong's "parting gift" to the Academy - as "one of permanent grace, in the pre-McLuhan tradition, although electronic resources are duly included" [Huxtable 1972: 40]. ${ }^{7}$ The Library housed not only "readers using books," but also patrons using microform, film, and cassettes. This building, according to the library committee's program, was to "affirm the regard at the Academy for the work of the mind and the hands of man" - and this work came in forms other than the codex [Phillips Exeter Academy 1966: 2]. In 1966, Armstrong's committee acknowledged that,

Today the function of the library has so changed that a new building should provide areas for creative independent study and for easy social exchange of ideas, contain seminar rooms for instruction in techniques of study and research, and house a wide variety of written and audio-visual accounts of man's achievements and aspirations. It must be equipped with microfilm viewers, tape recorders, slide and motion-picture projectors, record players and television receivers. Incorporating every facility that would today encourage cultural use, the new library must, nevertheless, be spacious enough to meet future demand and innovations [Phillips Exeter Academy 1966: 1-2].

Kahn of course provided space for independent study and social exchange, as directed. Yet these new media formats, with their own formal geometries, would present different spatial demands, and the library would have to accommodate them. However, Kahn's design, based on the metaphor of "tak[ing] the books and go[ing] to the light," is rooted in the "module" of the codex. His declarations about library Form typically address a very limited scope of contemporary library activities - perhaps purposefully. According to Andreotti, Kahn was highly critical of the "mechanized, anonymous character of contemporary libraries" and the notion of the library as "information center" 
[Andreotti 1984: 161], which is why he looked for inspiration in the historical accounts of monastic libraries. But was his understanding of the "existence will" of Library expansive enough, and sufficiently unbound to any particular historical context, to accommodate the rapidly changing ways in which academic and public libraries were, and are, translating that "will" into new services and media?

Modularity had become the norm in mid-century American library building. After World War II, many public and academic libraries began to integrate once-separate areas of book storage and reading; tables, carrels, and lounge seating were mixed in with freestanding bookshelves to give readers open and easy access to library materials [Kaser 1997; Oehlerts 1991]. These modular libraries were either square or rectangular in order to allow for easy rearrangement or upgradging. This "rectangularity," according to library historian David Kaser, was dictated by the "real library 'module' - the book itself" [1997: 130]. Exeter's rectangularity is likewise rooted in the book form, although Kahn's library is less modular than many of its predecessors or contemporaries.

But as most architects have come to realize in the past few decades, the book is not the sole library module (nor was it in the early 1970s) - and modularity is not the ideal library design. Architectural historian Abigail Van Slyck addresses the mistakes of much mid-century library design: "In theory, mid-century modular planning enlivened libraries by uniting books and readers. In practice, however, large rectangular footprints, uniform eight-foot-high ceilings, and harsh fluorescent lighting rarely made these building exciting or even pleasant places to be" [2000: 152]. According to Van Slyck, architects have eschewed the monotonous regularity of the modular building in favor of comfortable, inviting places with plenty of windows, skylights, and atria to invite natural light. There is a "renewed appreciation for the simple act of reading a book, as well as a sharp realization that modular libraries of the postwar ear failed to enhance that act" [Van Slyck 2000: 152].

Kahn sought, through his investigation of the monastic libraries, to "reawaken...[the] fundamental human desires and aspirations" - to read and to learn - and thereby create "a modern library that embodied a more complex and substantial understanding of individual and social experiences" [Kohane 1990: 130]. Kahn deserves credit for breaking away from the rational, positivist design strategies of the modernists; for rejecting the modularity of International Style library design; and for realizing that form follows not only use-function, but also an institution's symbolic or aesthetic functions. His Exeter library adequately captures, in brick and wood and concrete, the "experiences" of reading and learning - in both their intimacy and communality, their informality and formality. Yet his design remains rooted in a "codex" mentality, for which reading remains the primary function.

How does this library accommodate individual and social experiences that involve reading newer textual forms, or that require practices of media "consumption" that exceed the term "reading"? "Post-print" (by which I mean not an era after print, but an era defined by the coexistence of print and its successors - much as Ong's secondary orality is defined by the coexistence of orality and literacy) libraries, however, require a form quite different than that dictated by the book "module." Furthermore, these contemporary libraries "mean" more than reading and meeting; they also serve as community cultural centers, as digital media warehouses and "navigators" through this "sea" of information, as media production and transmission centers, and in a variety of other capacities. The library Form must therefore incorporate spaces that articulate these 
additional functions. How has Kahn's library incorporated new media forms and new service functions in the nearly forty years since its opening?

The 1966 library committee was prescient: they called for their architect to create spaces for all kinds of new technologies - including microfilm and microcard readers in the periodicals room; soundproof typing and listening rooms; seminar rooms that could be "transform[ed]...into a miniature auditorium for showing films, filmstrips, transparencies, and slides"; and even, for the card catalog area, an "electronic appliance observed at the Rockefeller Library" [Phillips Exeter Academy 1966: 8, 10], ${ }^{8}$ which was "comparable to a telephone jack, speeds communication of information to inquiring readers and contributes to the efficiency of routing at the circulation desk" [Phillips Exeter Academy 1966: 9]. They requested "small metal plates permitting connection of electrical utilities" in each carrel and recommended that the "whole library should be so wired as to permit at some later date reception of audio-visual transmissions from outside or within the building" [Phillips Exeter Academy 1966: 10, 20].

In January 1976, Jacqueline Thomas reported to the Friends that, "because all the carrels were wired when The Library was built, students are not restricted to the sound proof carrels in the basement but, with headsets, they can listen to cassettes throughout the building." Two years later, the Friends helped the library start a film collection, although librarian Henry Bragdon admitted that he thought "in the few years during which boys and girls are at school, the time is better spent reading and writing than in looking and listening" [1978]. That same year, alum Jim Ottaway donated the Bown Adams' collection of classic and silent films. The Friends celebrated the donation by gathering to watch The Phantom of the Opera in Rockefeller Hall. The next year, however, Bragdon wrote the group to ask if any of them happened "to possess projectors for $8 \mathrm{~mm}$ and/or 'super-8' silent film... and would be willing to part with them"; the Library didn't have the necessary exhibition equipment to make good use of its growing film collection [Bragdon 1979a, 1979b]. Shortly afterward Shapiro [1980b] reported that the library has a great collection of stereographs, too, "but no proper means of viewing them." Thomas admitted to me during my visit in January of 2009 that she's still searching for the equipment necessary to take advantage of the silent film collection.

The library was considering how to exploit its video resources, too. Shapiro reported to the Friends in September 1980 that the library's new “video resources could... be made immensely more useful if we had the necessary equipment to help establish a course in video production." A review of a 2009 course guide reveals that there still are no courses in video production at PEA. Yet the library was the first place on campus to have video technology, Edouard Desrochers recalled [2009], and teachers who wanted to use video in their classes had to report to the library's fourth-floor seminar room. "Like microforms," Shapiro said, "videotapes have emerged from the world of technology to take an important place in libraries" [1984b]. In 1983, 388 classes and 309 student group gatherings made use of the library's video resources [Shapiro 1984a].

These examples demonstrate that, rather than selecting their films and videos and "go[ing] to the light," the filmgoers met in Rockefeller Hall, while the video watchers gathered in an adaptable fourth-floor seminar room. The same qualities that make the arcades ideal for reading a book make it unsuitable for watching a film. These different media have different relationships to light - and although Huxtable regards Kahn's design as having a "pre-McLuhan quality," McLuhan's distinction between "lightthrough" and "light-on" media might help to explain the functionality of the building's 
geometries and materiality for reading and watching [McLuhan 1994: 129]. A book requires that light be cast on it, and ideally, this light would filter through a window. Video is presented via light through a monitor screen, but monitors don't mix well with light streaming through windows. Film requires that light be projected on a screen, ideally a screen in a dark room, positioned a sufficient distance from the projector; the projection space thus requires a particular geometrical form. Kahn's design, with its focus on books and light, did not prioritize these other forms of media reception; the building simply had to adapt to "accommodate" them.

But the Library was not concerned only with providing materials and spaces for watching; it was also a space for listening. By the mid 1970s, the Library had become the "reserve desk for required listening in courses in music appreciation. ... [The Library] purchased new equipment and relocated the listening area to accommodate growing demand. New equipment, complete cataloguing, and easier access than before have combined to encourage more leisure listening" [Bedford 1976]. Plus, more teachers were assigning poetry and dramatic recordings for their classes. Yet despite this new and improved listening area, in September 1979 Henry Bragdon reported to the Friends that "eventually we would like to have a music room" to make use of the library's growing collection of jazz records, sheet music, and musical scores.

New developments were combining these modes of listening and looking. In 1976 librarian Henry Bedford reported that the library had become home to the language laboratory, "with cassettes and portable equipment," but it wasn't until Fall 1982 that Shapiro wrote the Friends with news that the Modern Language Browsing Area" had appeared "on the mezzanine overlooking the main floor of Rockefeller Hall," above the circulation desk. According to Desrochers, the first floor mezzanine was "a blank screen when we moved into the building," [2009] and it was an obvious choice to accommodate these rapidly evolving collections (fig. 7). This new language area would house language books, for which new shelves would have to be built, and "all language records and cassettes in the Library's collection, as well as a turntable and cassette player. We have bought a new slide projector, and a screen has been installed for both slides and film.... The room will also feature maps, posters, foreign language games, and a bulletin board for information about opportunities abroad" [Desrochers 2009]. This small mezzanine space would become one of the most progressive spaces in the library, combining all material, in all media formats, in a particular subject area. Yet the space couldn't have been conducive to this experiment in "format-blind" collection; lighting and acoustic limitations would have made it difficult for students to "mix formats" - to, say, watch a film while another student attempted to read a book in the dark.

In 1991 Henry Shapiro paused to reflect on the media-inspired changes that the library had undergone in the previous two decades:

Entire new technologies have come into play since the building was occupied. One room is devoted to word processing, while three rooms include video equipment; a separate alcove is set aside for recorded books, and the music listening area has expanded from one to two rooms; two CD-ROM indexes of magazines and newspapers are available in the Periodicals Room. New ideas have increased the use and circulation of books (we still have lots of those!): special displays of paperbacks and of recent acquisitions appear on the main floor... [Shapiro 1991]. 


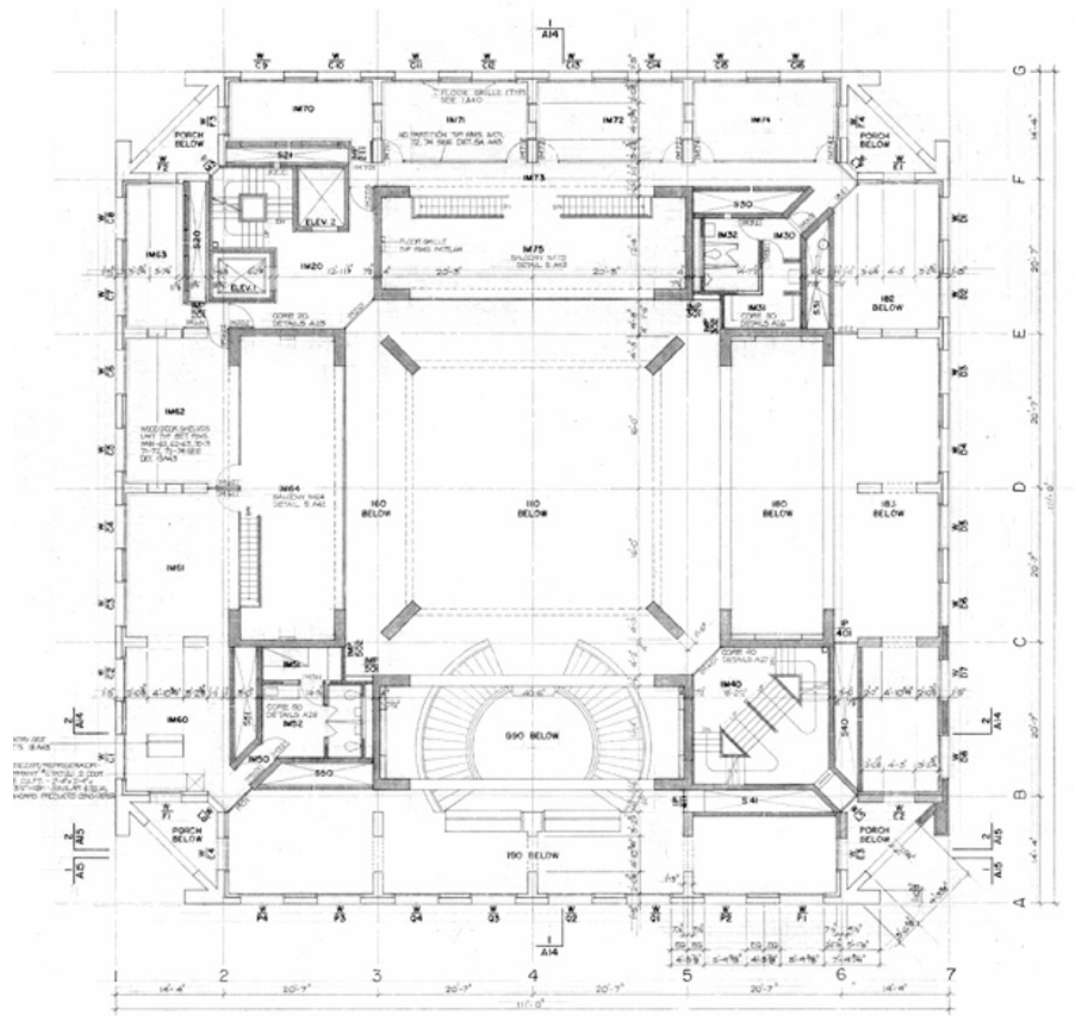

Fig. 7. Detail of the plan of the first floor mezzanine. Louis I. Kahn Collection, University of Pennsylvania and the Pennsylvania Historical and Museum Commission

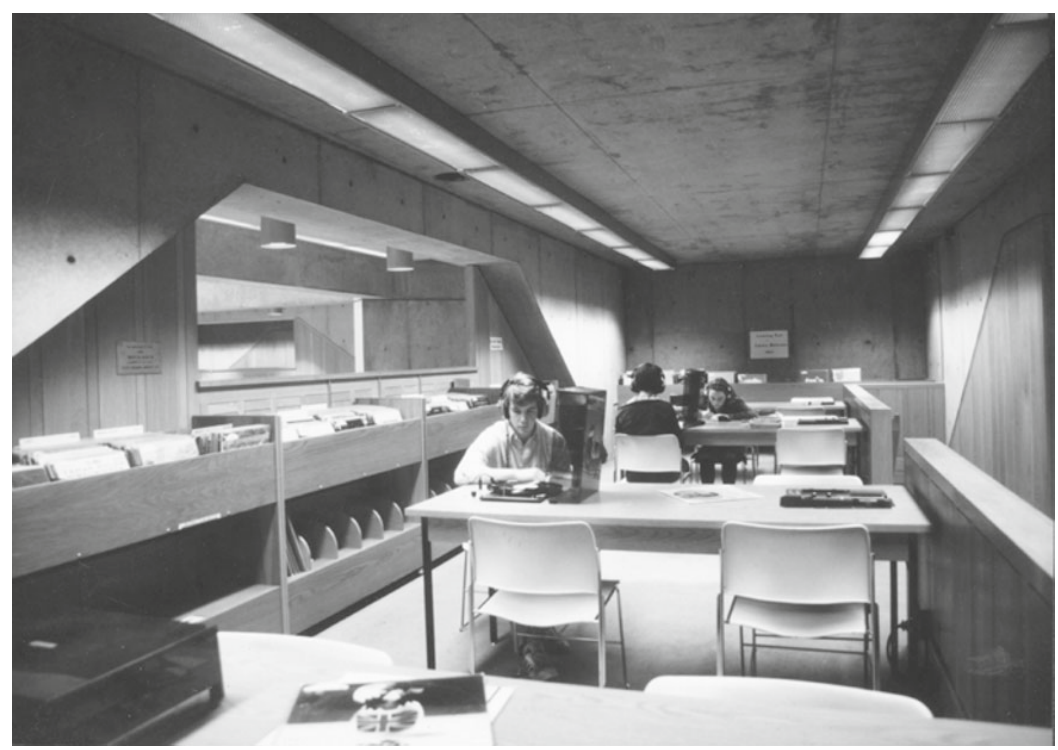

Fig. 8. Audio library. Photo courtesy of Dennis Waters 
Some spaces lent themselves more easily than others to technologically-driven changes. In the mezzanine language lab, Desrochers recalls, renovators had to pull wiring down from the lights to power the media equipment. LeCuyer also reported that "unsightly conduits have been face fixed across timber panels and brick walls alike" [LeCuyer 1985: 78]. Librarian Thomas said that the library was the "first place on campus to computerize" - yet she argues that, because the original design included chases for wiring and the carrels included outlets, the installation of cabling in 1994 was relatively painless [2009].

The first floor mezzanine spaces eventually became home to most of the audiovisual collections. When the modern language laboratory moved out of the Library, its former space above the circulation desk became the video library. The videos joined computer labs, staff offices, and the music collection and listening area in the southern part of the first-floor mezzanine (figs. 8 and 9). However, though these audio-visual collections were honored with dedicated space - albeit small, low-ceilinged rectangular rooms -, these spaces were accessible by only one of the main staircases and by separate staircases to the left of the circulation desk and hidden behind the card catalog. There is no direct passage (aside from routing through a staff area) between the CDs and DVDs; one must return to the first floor and go up a separate staircase to pass from one room to the other (fig. 7). These collections are disconnected not only from one another, into separate realms of sight and sound, but they are also segregated from the stacks above. Their marginalization is apparent even from the floor of Rockefeller Hall: the grand circular cutouts that frame the book stretch from floors two through four. Records, CDs, and DVDs are thus not enclosed within this window onto the landscape of knowledge. They, unlike the books, are not "treasures" worth framing.

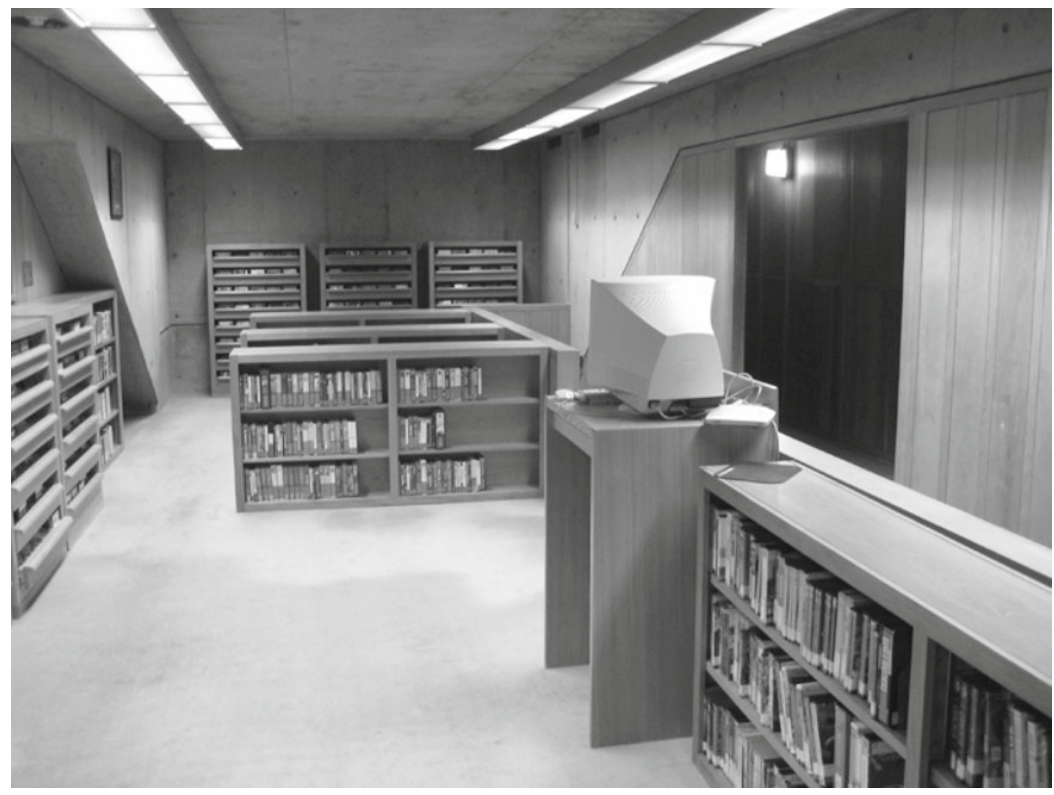

Fig. 9. Video library. Photo by the author 
In 2001, at the request of the Student Council, the Library opened CinemExeter, a collection of contemporary movies held in racks in front of the card catalog, near the circulation desk in the central hall. The movies' placement right by the check-out, and the commercial nature of their packaging, again suggest that these media are of an entirely different class than the books above. These are commodities intended to circulate - not within the building, in the way that books circulate between the stacks and carrels, but between the library and the outside world. Most students, Thomas said, check out the videos to watch in their dorm rooms. The Library isn't concerned with providing space for the serious contemplation of film; students, faculty, and staff (Thomas reported to me that CinemExter has drawn in many staff who had never before used the library) provide this space for themselves, outside the building's brick "screen" walls.

\section{The card catalogue}

The library itself acknowledges that " $[\mathrm{w}]$ hile no structural changes have been made to the interior of the Library, the usage of a number of areas has changed in the last three decades" [Phillips Exeter Academy, Changes and Renovations]. Kahn's triangles still draw the eye upward in Rockefeller Hall, his circles still frame the books, and his doughnuts still define the relationships between the various stages of research and the various components of a library's identity. Yet some of these geometries - the doughnuts, in particular - are used somewhat differently than they were in 1971, in part because the collection distributed throughout these geometric forms has evolved considerably in that time. Consequently, the map of that collection has evolved. Yet the quintessential material representation of that map - the card catalog - has maintained its prime location near the circulation desk; it's still the first thing visitors see after climbing the stairs to Rockefeller Hall (fig. 10).

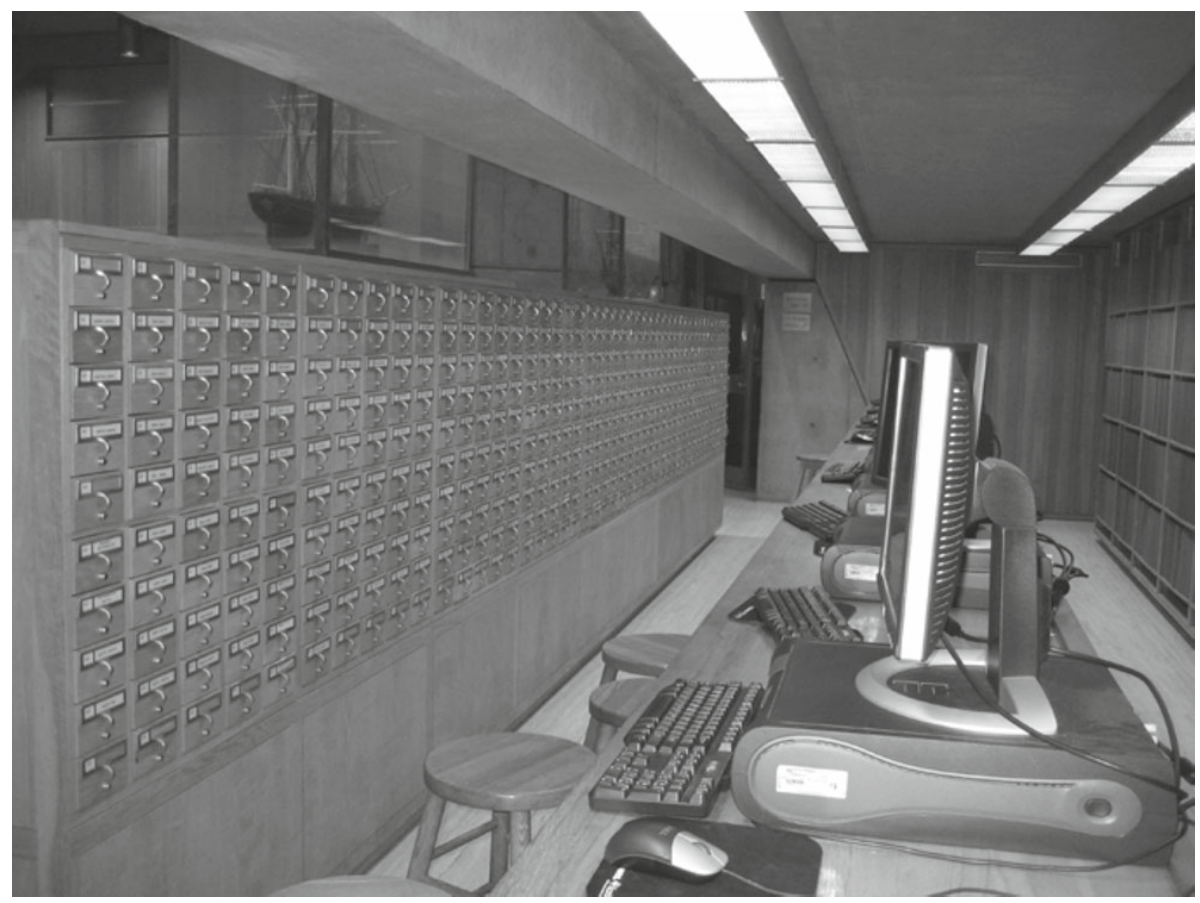

Fig. 10. Card catalog. Photo by the author 
This massive architectural furnishing, to whose geometric logic the planners gave some consideration in their library program, purports to embody the structural logic of the building. The codex is both the geometric and intellectual module of the building and the catalog is its heart.

Yet there hasn't been a card added to that catalog since 1994, when the online catalog went live. As the physical catalog lost its use value, the Library explains, it became a "beautiful artifact" [Phillips Exeter Academy, Changes and Renovations]. It, like the books stacked above and indexed within its drawers, is the building's "ornament." Except unlike the books, which are to be used and looked at, the catalog is merely a formal representation of the library's cultural heritage. Shapiro explained to the Friends in 1994:

The card catalog familiar to all of us will be retained in the Library, though new cards will not be added. It is an architectural feature of Rockefeller Hall in the Louis Kahn building, and it will also be a reassuring presence as those who are accustomed to it adapt to the new (digital cataloguing) system. Indicating the link between the old catalog and the new will be, symbolically, the name of the new system: BIBLION is the ancient Greek word or 'book,' and reminds us that the computer provides us with new ways of finding the books we need, not ways of forgetting about books or eliminating them from our research [Shapiro $1994]$.

Kahn is known to have drawn inspiration from ruins; Scully, we'll recall, described his library as "a diagrammatic realization of the Neoplatonic order indestructible within the ruin” [2003: 317]. This card catalog, a symbol simultaneously of loss and survival, is no less a rhetorical ruin.

Yet in the ground beneath this ruin, we might say, are seeds of the future. At roughly the same time that the card catalog was decommissioned, the Library set aside space in its basement, once used primarily to store periodicals and microforms, for the Academy's telecommunications (now Information Technology) department. "This is an immensely important and symbolic as well as technical step," Shapiro reported to the Friends in 1996. "All libraries are in a state of flux, as computer systems spring to life in the ether-, inter- and other-net-scapes." He continues, "Too often there is a tug between libraries and computer departments of a school or university, but the new location of our telecommunications department aligns the efforts at Exeter" [1996]. However, I gathered from my conversations with the librarians only a begrudging support of IT's presence in the basement; there seemed to be a resentment of IT's growth - not only its symbolic growth, as its "other-net-scapes" blanket the Gutenberg Galaxy, but also its physical growth, as its expanding servers and staff require more real estate on campus.

The only above-ground analogue for IT's subterranean presence is the library's wireless network. Kahn considered how new technologies should impress themselves upon design: "The world cannot be expected to come from the exercise of present technology alone to find the realms of new expression. I believe that technology should be inspired" [Kahn 1971: 33-4]. Christian Norberg-Schulz has taken this to mean that engineering is essentially integrated with Design, and both are equally inspired by Form [1979: 32]. Yet, in a Form like a library, where "technology" is integral to the very essence of the building type, we might also consider how "inspired [learning] technology" might generate a realm of "new [architectural] expression." Aside from the computers sprinkled throughout the building, the plasma television attached to the wall in the 
ground-floor Periodicals Room, and the immaterial presence of the wireless network - a "space" whose rhetoric is chiefly non-architectural and non-Euclidean - we find no expressions integral to the architectural design that reflect the "inspiration" of new media technologies.

Instead, what is reflected in Kahn's design is the fixity of print, its locked position on the printed page. We might argue that the Class of 1945 Library remains frozen in the light of the Enlightenment, unable to represent in its geometric spaces the non-geometric nature of post-print media and the disorder of nonlinear, hyperlinked modes of learning. Jordy wonders "to what extent (if at all) did the quest for primal meaning founder in somewhat contrived archaism and inflated monumentality?” [1974: 330]. Did Kahn's insistence on "first beginnings" - his use of the basic forms, the structural essence of the library institution - preclude the creation of an institution that is functional today, and in the future? Douglas M. Knight, Chairman of the Friends, wrote to the group in June 1980 , to address the relationship between the library's timeless values and contemporary challenges:

As we reflect on the past centuries all of us are aware that the great changes are not in the ends of education but in the means of attaining those ends. I doubt that we are wiser than we were in 1781 , but we certainly have to make our way through a more tangled maze of information in order to reach some small state of wisdom.

For me the Library embodies this shift and this need more clearly than any other aspect of the Academy. Its variety of resources and services is essential in a world as urgent and complex as our own [Knight 1980].

The library's ordered geometry, however, speaks not of this "tangled maze," but of rationality, stability, tradition. This place is not "urgent and complex," but, rather, timeless and essential. We must wonder about the appropriate relationship between this cultural space and the culture out of which it arose, and to which it contributes. Should the library function rhetorically as a synecdochic representation of, formally and epistemologically similar to, this "urgent and complex" world? Or should it represent an alternative to that complexity, a space of exception?

\section{Acknowledgments}

I would like to express my sincere thanks to Jean-Louis Cohen, who encouraged me to begin this research in graduate school; to Robert Kirkbride; to Jacqueline Harris, Ed Desrochers, and other library staff members at Phillips Exeter Academy; and to the staff at the Architectural Archives of the University of Pennsylvania.

\section{Notes}

1. Since the brick was produced in Exeter - it was the last batch produced by a company going out of business - it has ties to its local context [Huxtable 1972: 33].

2. Photographs of the building's exterior are readily available online, so I have not reproduced any such images in this essay.

3. For the 2008-9 school year, tuition and fees were roughly $\$ 38,000$.

4. The assignment of carrels is a recurring debate and a heated political issue: Library staff and students have varied between prioritizing day students, who have no dorm rooms in which to keep their school materials, and prioritizing upperclassmen.

5. In letters to Kahn, librarian Rodney Armstrong [1966a; 1966b], responding to the architect's initial drawings, recommended particular adjacencies and groupings of library functions; Armstrong paid particular attention to the services offered on the first floor. 
6. It is significant that boy couldn't meet girl - and girls' voices couldn't be heard in the library until 1970, when the library went co-ed

7. McLuhan is again evoked in an unpublished document titled "Library Pitch" and attributed to "Bedford," whom we might assume is Exeter history teacher Henry Bedford. Bedford, citing McLuhan's famous phrase, "the medium is the message," acknowledges that PEA's library conveys messages about the institution's values. While McLuhan, Bedford claims, "has been preaching that print is not only square, but well on the way to extinction, "Exeter wants to say that books are important... A school's educational philosophy, and the values of its alumni, are manifest in its building program. The Exeter faculty affirms, with full confidence that the alumni concur, that everything still rests on a boy and a book, and a place where the two can comfortably get together" [Bedford? 1968: 9-10].

8. In a letter to the Friends of the Academy Library, Henry Bedford acknowledged that "microfilm just is not very sexy. Indeed reading it, somebody once remarked, is like kissing your girlfriend through a window pane... [Yet] few people are sentimentally tied to brittle newsprint, and no library any longer can store and bind volumes of newspapers" [1977].

\section{References}

Andreotti, Libero. 1984. Conceptual and Artifactual Research Programmes in Louis I. Kahn's Design of the Phillips Exeter Academy Library (1966-72). Design Studies 5, 3 (July 1984): 159-65.

ArChitectural Forum. 1972. The Mind of Louis Kahn. Architectural Forum 137 (July/August 1972): 76-77.

ARMSTRONG, Rodney. 1966a. Letter to Louis I. Kahn, May 27, 1966. Louis I. Kahn Collection, Box 030.11 \#7, Folder 030.11.A.6.1, Architectural Archives of the University of Pennsylvania, Philadelphia, PA.

1966b. Letter to Louis I. Kahn, August 18, 1966, Louis I. Kahn Collection, Box 0.30.11 \#7, Folder 030.11.A.6.1, Architectural Archives of the University of Pennsylvania, Philadelphia, PA.

[Bedford, Henry?]. Library Pitch. 1968. January 8, 1968, Louis I. Kahn Collection, Box 030.11 \#7, Folder 030.11.A.6.2, Architectural Archives of the University of Pennsylvania, Philadelphia, PA.

BEDFORD, Henry F. 1976. Letter to the Friends of the Academy Library, July 1976; reprinted in Friends of the Academy Library, Collected Letters. Phillips Exeter Academy, n.d.

- 1977. Letter to the Friends of the Academy Library, March 1977; reprinted in Friends of the Academy Library, Collected Letters. Phillips Exeter Academy, n.d.

Bourdieu, Pierre. 1972. The Logic of Practice. Rpt. Cambridge: Polity Press, 1990.

BRAGDON, Henry W. 1978. Letter to the Friends of the Academy Library, April 1978; reprinted in Friends of the Academy Library, Collected Letters. Phillips Exeter Academy, n.d.

- 1979a. Letter to the Friends of the Academy Library, May 1979; reprinted in Friends of the Academy Library, Collected Letters. Phillips Exeter Academy, n.d.

- 1979b. Letter to the Friends of the Academy Library, September 1979; reprinted in Friends of the Academy Library, Collected Letters. Phillips Exeter Academy, n.d.

BrownleE, David and David De Long. 1991. Louis I. Kahn: In the Realm of Architecture. New York: Rizzoli.

Desrochers, Edouard. 2009. Personal Communication, January 12, 2009.

Dover, Kim. 2005. The Silent Complicity of Architecture. Pp. 283-296 in Habitus: A Sense of Place, 2nd ed., Jean Hillier and Emma Rooksby, eds. Burlington, VT: Ashgate.

ECO, Umberto. 1997. Function and Sign: The Semiotics of Architecture. Pp. 181-201 in Rethinking Architecture: Reader in Cultural Theory, Neil Leach, ed. New York: Routledge.

FORTY, Adrian. 2000. Language Metaphors. Pp. 62-85 in Words and Buildings: A Vocabulary of Modern Architecture. New York: Thames \& Hudson.

GAST, Klaus-Peter. 1999. Louis I. Kahn. Boston: Birkhäuser.

Goldhagen, Sarah Williams. 2001. Louis Kahn's Situated Modernism. New Haven: Yale University Press. 
GreER, Peter C. 1991. Letter to the Friends of the Academy Library, January 1991; reprinted in Friends of the Academy Library, Collected Letters. Phillips Exeter Academy.

- 1999. Letter to the Friends of the Academy Library, February 22, 1999; reprinted in Friends of the Academy Library, Collected Letters. Phillips Exeter Academy.

HALE, Jonathan. 2000. Systems of Communication. Pp. 131-170 in Building Ideas: An Introduction to Architectural Theory. New York: John Wiley \& Sons.

Hall, Edward T. 1959. Space Speaks. Pp. 162-185 in The Silent Language. New York: Anchor.

Huxtable, Ada Louise. 1972. New Exeter Library: Stunning Paean to Books. New York Times (October 23, 1972): 33, 40.

JAMES, Sally Murray. 1993. Seeking Light. Unpublished essay, November 1993; reprinted in Friends of the Academy Library, Collected Letters. Phillips Exeter Academy, n.d.

JordY, William H. 1974. Criticism: Kimbell Art Museum, Fort Worth, Texas; Library, Phillips Exeter Academy, Exeter, New Hampshire. Architectural Review 155, 928 (June 1974): 330335.

KAHN, Louis I. 1961. A Statement by Louis I. Kahn” Arts and Architecture (February 1961): 465. Rpt. 2005: Form and Design, pp. 464-471 in Robert McCarter, Louis I. Kahn, New York: Phaidon.

- 1965. Space Form Use: A Library" Pennsylvania Triangle 43 (December 1965): 43-47. Toynbee, et al. New York: Viking Press. Rpt. 2005: Architecture: Silence and Light, pp. 472479 in Robert McCarter, Louis I. Kahn, New York, Phaidon.

- 1971. The Room, the Street, and Human Agreement. AIA Journal 58, 3 (September 1971): 33-34. Rpt. 2005: Pp. 480-485 in Robert McCarter, Louis I. Kahn, New York, Phaidon.

KASER, David. 1997. The Evolution of the American Academic Library Building. Lanham, MD: Scarecrow Press.

KAWASAKI, Kazumi. 1983. Thoughts About Louis I. Kahn. Architecture and Urbanism, November 1983: 216-236.

KNIGHT, Douglas M. 1980. Letter to the Friends of the Academy Library, June 1980; reprinted in Friends of the Academy Library, Collected Letters. Phillips Exeter Academy, n.d.

Kohane, Peter 1990. Louis I. Kahn and the Library: Genesis and Expression of 'Form'. Pp. 98131 in VIA: Ethics and Architecture 10, John Capelli, Paul Naprstek and Bruce Prescott, eds. New York: Rizzoli.

Koyama, Hisao 1983. Louis I. Kahn and His Times. Architecture and Urbanism, November 1983): 19-23.

LECUYER, Annette. 1985. Evaluation: Kahn's Powerful Presence at Exeter. Architecture (February 1985): 74-79.

MarLin, William. 1973. Within the Folds of Construction. Architectural Forum 140, 3 (October 1973): 26-35.

MATtern, Shannon- 2007. Resonant Texts: Sounds of the American Public Library. The Senses \& Society 2, 3 (Fall 2007): 277-302.

MCCARTER, Robert. 2005. Louis I. Kahn. New York: Phaidon.

MCLuHAN, Marshall. 1994. Understanding Media: The Extensions of Man. Cambridge: MIT Press.

MulLER, Brook. 2008. Metaphor, Environmental Receptivity, and Architectural Design. Pp. 185203 in Symbolic Landscapes, Gary Backhaus and John Murungi, eds. New York: Springer.

Norberg-Schulz, Christian. 1979. Kahn, Heidegger and the Language of Architecture. Oppositions 18 (1979): 29-47.

Oenlerts, Donald E. 1991. Books and Blueprints: Building America's Public Libraries. New York: Greenwood.

ONG, Walter. 1982. Orality \& Literacy: The Technologizing of the Word. New York: Routledge. PHILLIPS EXETER ACADEMY. Academy Archives. http://www.exeter.edu/libraries/4513_4623.aspx?tab=2. Accessed January 12, 2009.

- Changes and Renovations. http://www.exeter.edu/libraries/4513_4535.aspx. Accessed January 12, 2009. 
. Design of the Library. http://www.exeter.edu/libraries/4513_4522.aspx. Accessed January 12, 2009.

. The Harkness Table. http://www.exeter.edu/306/pages/aca_harknesstable.html. Accessed January 12, 2009.

. The History of Harkness Teaching. http://www.exeter.edu/admissions/147_5238.aspx. Accessed January 12, 2009.

- 1966. Program of Requirements for the New Library Recommended by the Library Committee of the Faculty. Exeter, NH, June 1966.

Russell, James S. 1997. The Richness of Louis Kahn's Exeter Library Stands the Test of Time. Architectural Record (May 1997): 94.

SCully, Vincent. 1989. Introduction. Pp. 14-44 in Kahn: Libraries-Bibliotecas. Xavier Costa, et al. Barcelona: Publicaciones del Col.Legi d'Arquitectes de Catalunya.

- Modern Architecture and Other Essays (Princeton: Princeton University Press, 2003).

SHAPIRO, Robert N. 1980a. Letter to the Friends of the Academy Library, September 1980; reprinted in Friends of the Academy Library, Collected Letters. Phillips Exeter Academy, n.d.

- 1980b. Letter to the Friends of the Academy Library, December 1980; reprinted in Friends of the Academy Library, Collected Letters. Phillips Exeter Academy, n.d.

- 1982. Letter to the Friends of the Academy Library, Fall 1982; reprinted in Friends of the Academy Library, Collected Letters. Phillips Exeter Academy, n.d.

. 1984a. Letter to the Friends of the Academy Library, January 1984; reprinted in Friends of the Academy Library, Collected Letters. Phillips Exeter Academy, n.d.

. 1984b. Letter to the Friends of the Academy Library, June 1984; reprinted in Friends of the Academy Library, Collected Letters. Phillips Exeter Academy, n.d.

. 1984c. Letter to the Friends of the Academy Library, September 1984; reprinted in Friends of the Academy Library, Collected Letters. Phillips Exeter Academy, n.d.

. 1985. Letter to the Friends of the Academy Library, June 1985; reprinted in Friends of the Academy Library, Collected Letters. Phillips Exeter Academy, n.d.

- 1986. Letter to the Friends of the Academy Library, June 1986; reprinted in Friends of the Academy Library, Collected Letters. Phillips Exeter Academy, n.d.

. 1988. Letter to the Friends of the Academy Library, October 1988; reprinted in Friends of the Academy Library, Collected Letters. Phillips Exeter Academy, n.d.

. 1991. Letter to the Friends of the Academy Library, September 1991; reprinted in Friends of the Academy Library, Collected Letters. Phillips Exeter Academy, n.d.

- 1992. Letter to the Friends of the Academy Library, February 1992; reprinted in Friends of the Academy Library, Collected Letters. Phillips Exeter Academy, n.d.

. 1994. Letter to the Friends of the Academy Library, June 30, 1994; reprinted in Friends of the Academy Library, Collected Letters. Phillips Exeter Academy, n.d.

. 1996. Letter to the Friends of the Academy Library, October 1996; reprinted in Friends of the Academy Library, Collected Letters. Phillips Exeter Academy, n.d.

-1997. Letter to the Friends of the Academy Library, July 1997; reprinted in Friends of the Academy Library, Collected Letters. Phillips Exeter Academy, n.d.

. 2002. Letter to the Friends of the Academy Library, October 2002; reprinted in Friends of the Academy Library, Collected Letters. Phillips Exeter Academy, n.d.

THOMAS, Jacquelyn H. 1976. Letter to the Friends of the Academy Library, January 1976; reprinted in Friends of the Academy Library, Collected Letters. Phillips Exeter Academy, n.d.

. 2009. Personal communication, January 12, 2009.

VAN SLYCK, Abigail. 2000. A New Chapter. Architectural Record (October 2000): 151-153.

WicKerSHAM, Jay. 1989. The Making of Exeter Library. Harvard Architecture Review 7: 138-49.

Wiggins, Glenn E. 1997. Louis I. Kahn: The Library at Phillips Exeter Academy. New York: Van Nostrand Reinhold.

Wurman, Richard Saul, ed. 1986. What Will Be Has Always Been: The Words of Louis I. Kahn. New York: Access Press and Rizzoli. 


\section{About the author}

Shannon Mattern is Assistant Professor and was, through Spring 2009, Director of Graduate Studies, in the Department of Media Studies and Film at The New School in New York. Her book, The New Downtown Library, was published by University of Minnesota Press in 2007, and other essays examining various relationships among media, architecture and urban planning have appeared in the Journal of Architectural Education, The Senses \& Society, International Journal of Communication, Public Culture, and Space and Culture, among others. 